\title{
A STUDY OF THE TIPULA FRATERNA COMPLEX IN THE SOUTHEASTERN UNITED STATES (TIPULIDAE: DIPTERA)
}

By

C. DENNIS HYNES

\begin{abstract}
A DISSERTATION PRESENTED TO THE GRADUATE COUNCIL OF THE UNIVERSITY OF FLORIDA IN PARTIAL FULFILLMENT OF THE REQUIREMENTS FOR THE DEGRE OF DOCTOR OF PHILOSOPHY
\end{abstract}

UNIVERSITY OF FLORIDA

August, 1957 


\section{ACKNOWHWTGMNTS}

I wish to thank Dr. Lewis Berner for giving we the assistantship available through National Institutes of Health Grent $0-4058$ which made this study possibleg but I especially wish to thank hin for his direction, encouragement, and many valuable suggestions throughout the course of the Investigation.

I also want to express $\mathrm{gy}$ appreciation to the late Dr. J. S. Bogers, former Director of the University of Michigan Kuseum of 20010gy, for Inttial gutdence in selecting this problean and to thank Dr. T. H. Hubbell, present Director of the Nuseum, for making the former's material avatlable to ase for study.

I an also grateful to the following?

Dr. C. P. Alexcander, University of Nassachusetts, for hla interest and encouragement throughout this investigation; Doctors J. H. Davis, J. H. Gregg, A. B. Grobman, and H. K. Wallace for reading this dissertation and for suggestions offered during this study; Dr. H. T. Townes of the Iniversity of Michlgan Nuseum of Zoology for specinens of the tricolor group from his private collection; Dr. Thelma Howell, Director of the Highlands Blological Station, for the use of the Station as a bese of operations while I was collecting in North and South Carolinas Dr. A. M. Laessle for determination of plants within the habitat of I. Praternas Dr. R. F. Hussey for assistance with certain taxonomile aspects of the studys Mr. W. D. Reese and Mr. R. A. Purcell of Florida State University for deterzination of Bryophytes. 


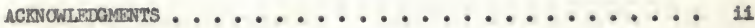

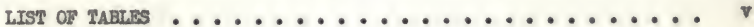

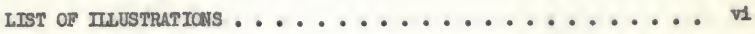

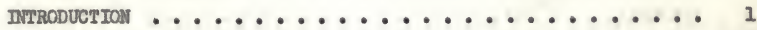

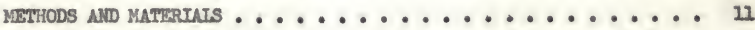

GEOGRAPHTC DISTRIBUTION OF THE COMPLEXES .......... 17

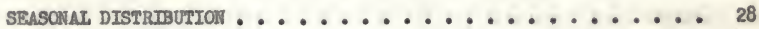

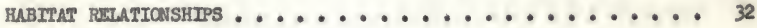

LTS HISTORI . . . . . . . . . . . . . . . . . 39

MORPHOLOGTCAT FEATURTS OF THE ADULT ............ 47

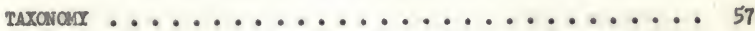

T. fraterne ...................... 57

T. confraterna $\ldots \ldots \ldots \ldots . . . \ldots 73$

Intergradation of $\mathrm{T}_{0}$ fraterna and To strepens ...... 85

Description of Ileotype of To freterna ......... 89

Description of Tipula confraterns sp. n. ....... 92

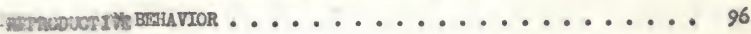

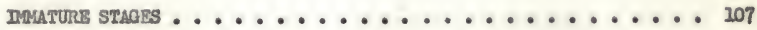

Egg . . . . . . . . . . . . 107

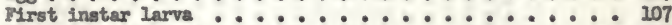

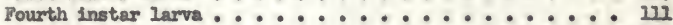

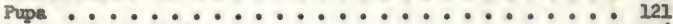

Pupa of $\mathrm{T}_{\mathrm{f}}$ confraterna ............. 126

STATUS OF THE PRATEFA COMPLBX IN RELATION TO THE OTHRR

COMPLBXTES OF THE TRTCOLOR GROUP? ............. 129 


\section{TABIE OF covrears-continued}

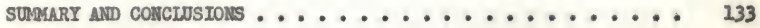

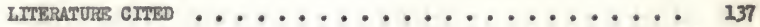


LIST OF TABLES

Table

Page

1. Species of the Gemus Tipula in North America

with which this paper is concerned .........

2. Iengths in rum. of all Stages of I. fraterna and

Larval Head Capsule Lengths ........... 44

3. Percentage of Individuals from the Gadsden County

Series showing fraterne, plorldensis, and inter-

mediate Types of Setse Distribution on outer

Dististyles ...................

i4 Percentage of Individuals from Several Southeastern Samples Grouped Together Shoving fraterns,

Ploridensig, and Internediate Types of Setal

Distribution on outer Dististyles ..........

5. Results and Analjoss of Wing and Body

Heasurements ...................

6. The Percentage of Individuals in Gadsden County Series Showing White or If ght Arees in Wing Cells.. 
IIST OF IHWUSTRATIONS

Figure

1. Genstal structure of Tipula Iudoviciana as representathive of sevi complex ............... 7

2. Genital structure of Iipula furcs as representative of rures complex ................ 7

3. Map showing areas collected in southeastern states... 19

4. Distribution of savi conglex ............. 19

5. Dlatribution of fures complex ............ 19

6. Distribution of caloptera complex .......... 19

7. Distribution of trieolor complex .......... 21

8. Distribution of concava conglex ............ 21

9. Distribution of Mipula strepens ........... 26

10. Distribution of Mpuls fraterma ............. 26

11. Map shoving so11 grougs, fall-1ine, and $60^{\circ}, 65^{\circ}$, and

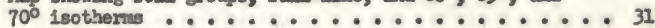

12. Distribution of Mpuls conffaterna .......... 31

13. Graphic representation of lengthe of all atages of Tipula fraterna, larval head-capeule, and longevity

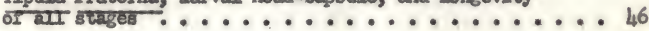

14. Structures of heed and thorax of Iypula fraterna . . . . 50 15. WIng venation of Iloula fraterna ............ 50

16. Male Hypopygial structures of Tlpula fraterna ..... 53

17. Female Fypopygiel structures . . . . . . . . 56

18. Setal distribution of fraterna type outer dististyle . . 66 v1 


\section{LIST OF IILUSTRArIONS-continued}

\section{Figure}

19. Setal distribution of porldensis type outer dististyle. - 66

20. Strepmshaped sten of outer dististyle ........ 66

21. Irregular shaped sten of outer dististyle ....... 66

22. Nearly straight outer dististyle .......... 66

23. Curved outer dististyle .............. 66

24. Varlation in distal tips of dististyle of specinens of Gadsden County Serles ............. 72

25. Basio ving pattern of Mipula fraterna ........ 72

26. Variation in basic wing pattern of Tipula fraterna vith white in cell $\mathrm{R} 4+5 \ldots \ldots 75$

27. Variation in basic wing pattem of P1pula fraterna with whita in cell $\mathrm{M}_{1} \ldots . . . . . . . . . . .75$

28. Variation in basic wing pattern of Ipurs ersterns wth white in cell $\mathrm{H}_{2} \ldots . . . \ldots 75$

29. Varlation in basic wing pattem of Iipula Iraterna with white in cells $\mathrm{R}_{3}$ and $\mathrm{R}_{4}+5 \ldots \ldots 75$

30. Variation in basic uing pattern of Mpula fraterna found in Stone County, Kississippi, and the Littio Escambia River in Escarbis County, Nlabema . . . . . 78

31. Variation in wing venation of Tipula fraterna showing

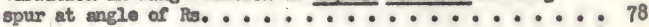

32. Basle wing pattern of Tipula confraterna ........ 80

33. Varlation in basic wing pattern of I1pule confraterna

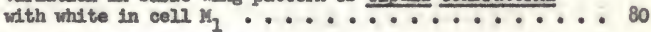

34. Variation in basic wing pattern of Iipuls confraterna vith white in cell $\mathrm{M}_{2}$ 


\section{ITST OF IILUSTRATIONS-cont1mued}

Flgure

35. Variation in wing venstion of Tinura confraterns

wth extra vein in cell $\mathrm{N}_{2} . . . . . . . . . .$.

36. Comparison of tergo-lobe angles of mipula fraterna

and Tipula confraterna ............... 82

37. Basic wing pattern of Tipula strepens ........ 84

38. Variation in basic pattern of Mpule strepens ..... 84

39. Inner dist1atyle of Mipula stregens ......... 88

40. Inner dist1style of Mpula Iraterna ......... 88

41. Sketch of aedeagus and lateral arms of Mpule

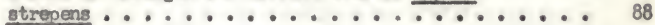

42. Tergo-iobe and outer dististyle of neotype of

Mpula fraterna .................. 95

43. Holotype of Mpula confraterna, tergo-lobe and

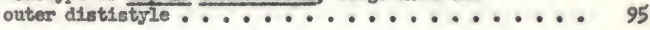

44. Poaition of cenital strictures of male and fenale

Tipula fratema during copulation ......... 100

45. Egg of TIpula fraterna .............. 109

46. Tipule fraterna, gpiracular disk of Prst Instar

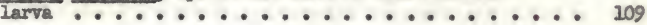

47. Mipula fraterne, anal lobes of Iirst Instar larva. . . 109

48. Tipula fraterna, head cepsule of I1rst instar Iarva. . 109

49. Mipula fraterna, maxdilary plate of f1rat instar Iarva ................... 113

50. Tipula fraterna, clypeal-labral region of flrst instar Larva ..................... 
LIST OF THUSTRAYIONS-continued

Figure

51. Tipula fraterna, mandible of f1rst instar larva. . . . 113

52. Hipula fraterns, lateral view of fourth instar

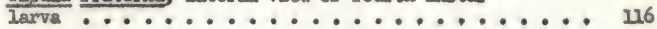

53. Setal type which gives partial black coloration to anterior body segments of Tipula fraterne larva. . . . 216

5ls. Chaetotaxy of segments of Mpule Preterns fourth

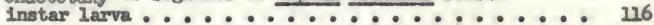

55. Tipula fraterna, spiracular disk of fourth Instar

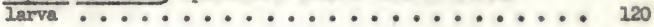

56. Tipula fraterns, mandible of fourth Lnstar lerva . . . 120

57. Tipula fraterna, prosthecal tuft of mandible ..... 120

58. Tipula fraterna, madila of fourth instar larva . . . 120

59. Tipula fratema, antenna of fourth instar 2arva ... 120

60. Tipuls fraterns, maxdllary plate of fourth Instar Iarva .................. 123

61. Wipula fraterna, promentum of fourth instar lerva ... 223

62. Tipula fraterna, pupa ............. 228

63. Tipule confraterns, wing pad of prqe........ 128

64. Diagram showing relationship of fratema complex to other complesces ............. 132 


\section{INTRODUCTION}

There are vithin the Ipulidee several groups of closely related species which are called specles complexes by the workers in this Pleld. These species are nearly the sune with respect to morphological appearances, and many times overlap alnost completely in ell othar details of their blology. On the basis of slight morphological differences, ner spectes have been named and, in other cases, species have been symonomized with no certatnty as to the validity of ame forms within these species complexes. Such a situation is found in many genera of crane-flies, including the genus T1pula 1tself. Rogers (19/42) calls attention to this situation within the genus IIpula by stating that, "the not infreguent existence in the Iipulidae of two closely similar species that have identical or very similar geographical ranges and habitats merits further study." He goes on to mention, as excamples, the group composed of I. hirsuta and T. valida vithin the subgenus Lunatipula, I. elute and T. fures within the cubgenus Yamatotipuls, and the I. triplex group, also vithin the rubgenus Lunatipula. He believed that the possibility of genetic dimorphisen within one species could not be "absolutely disulssed." Within the genus Tipula and subgenus Yematotipula, the trycolor group Includes several species conglexses, which in turn appear to be very closely related. The so-called fraterns complex is one of these. Through the study of the specles malding up the fraterns complex, further lnowledge right be gained about the texonomilc standings of the various 
species which, in turn, might jleld some perspective to the relationships of this group and with groupe closely related to 1t. Mlthough this work Is primarily concemed with the eraterne complex, it is Impossible not to refer to specles of the other complesses for bacleground or aupporting evidence, and this has been done quite freely throughout this paper. The apecies of the genus Mipula in North America with which this paper is concerned are shown in Table 1 ,

\section{TABIS 1 ,}

$$
\begin{aligned}
& \text { SPECINS OF THE GLNUS TIPUIA } \\
& \text { IN HORTH AMRRICA WITH WHLCH } \\
& \text { THIS PAPEA IS CONCERNED } \\
& \text { Complex } \\
& \text { Specles } \\
& \text { says } \\
& \text { T. sav1 } \\
& \text { Ii Iudoviciana } \\
& \text { T. osceols } \\
& \text { furea } \\
& \text { T. furce } \\
& \text { T. } \frac{\text { Vicins }}{\text { eluts }} \\
& \text { calopters T. caloptera } \\
& \text { I. noveboracens1s } \\
& \text { tricolor To tricolor } \\
& \text { T. manahatta } \\
& \text { T. subeluta } \\
& \text { T. sackentana } \\
& \text { concava Ii concava } \\
& \text { fraterna T. fraterna } \\
& \text { T. floridensis } \\
& \text { T. naculípleura } \\
& \text { T. strepens } \\
& \text { T. ealopteroides }
\end{aligned}
$$

The subgemus Yanatotipula was first defined by Matsunura (1916) 
as having generic rank and later reduced to subgeneric rank, brosdened, and redefined by Alexcander (1935). The characters which separate this subgemus from othors of the genus Tipula are adequately described in Alexander (1935, 1942), The subgenue is holarotic in distribution and grobably contains between sixty and seventy specles. $\underline{T}_{0}\left(\underline{Y_{0}}\right)$ lamelcensis Alexc, a neotropical species from the Greater Antilles, is the only nonholaretic species. Mlexander (1951) belleves I. Lamaicensis to be

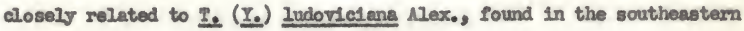
United States.

The subgenus has evidently evolved along two alternative lines, one having wings with a pattern of brown and pale white longltudinal stripes, and the other without any pattern on the wings. The forner line $18 \mathrm{knom}$ as the so-called tricolor group in the nearetic region.

Pogers (personal communteation) stated that the tricolor group could be still further divided into several more or less natural spocies complexes and, before his death, did rention the species which ho bolieved ande up the various conplessos; however, he did not specify what he considered to be the limitations or definitions of each. I agree with Rogers about the composition of most of the complexes and have, in the following paragraphs, attenmted to give the characteristies by which I belleve each cen be separated. The main characteristics used to separate these complexes are the wing patterns, especially at the tips beyond the cord, and details of the genitalia. The userulness of these complexes wlll be shown later during the discussion of the relationships of the species Involving the fraterna complex. In the eastern United States the tricolor Eroup diverges Into two general innes. One is 
4

charecterized by the wings having only one dark brown stripe along the coatal border of the wing ending at the Sc2 and R I+2 cells of the wings. Nembers of the sayi complex fall Into this group in which Rogers placed the species I. sayl, I. osceola, and I. Iudovicians, stating that the areas elong the Gulf Cosst and Inland Florida flatwoods have many epparently Intermediato populations between sav1 and osceola. He belleved ludovicians to be clearly related but apparently quite distinct from the others. The genitalla of the species within this complex have a basic pattern with the outer dististyle ovate, the Inner dististyle with the basal lobe elongate as in ludovleians, or shorter and bulbous as in osceola (FIg. 1). The dististyles of all the species are weakly ohitinized.

The second divergent 11 ne of the tricolor group involves several compleaces, all having a dark brown stripe or vitta along the coatal edge of the ring. The stripe 18 sometimes broken at the cord, then continues into cells Se2 and R 1+2. Another stripe of dark brown occurs along the veins $\mathrm{Cu}$ and mecu of the wing.

The calopters complex has two distinct apecies. These are I. (1.) calopters and T. noveboracensis. In both, the pale areas of the wing occur in the anterior two-thinds of the cell $\mathrm{H}$, along the cord, dipping around the edge of the m-cu into the inner half of the cell Mh and the distal two-thirds of the cell lst N2, then along the inner portions of the cells M3, Y2, the imer fourth of cell MI and the distal half of the cell R 4+5, glving the pale whitish stripe pattern from the cell M to $R \quad 4+5$ a simuate appearance at the cord. The besic pattern of the ninth tergo-lobes are simllar, having one prominent medial lobe and two analler lateral 2obes. In T. caloptere the medial lobe onls is well 
developed and moderately chitinised, while in I. noveboracensis all the lobes are heavily chitinised and appear black. Detalls of the dististyles lesve no doubt that the two are definftely separete species,

The enres complex contains three species of which one, I. (I.) Fieina, is distinctly northern. The others, $\underline{T}_{\text {. }} \underline{Y}_{0}$ ) furce and eluta are not as distinct and their validity was questioned by Rogers. The general wing pettern of all the species within the erren complex is characterised by the pale white stripe of the wing extending nore or less in a straight Iine from the cell $M$ to the distal edge of the coll $\mathrm{R} 4+5$ with no simate appearance at the cord. In furce a dark ares dips into the pale white area of cell $R$, giving the stripe at this point a bisinuate appearance, whereas eluta does not have this character. I have been unable to obtain specimens of I. eluta for study and camnot comvent further on thls species. The geritalla of vicina and furca are simdlar, with the outer dististyle lobed at the base, the distal portions nearly the sane; that of furca longer and more slender than that of vicina. The inner dististyle and tergo-lobe are also of the same basic shape (Hg. 2).

The twascos complex (not to be confused with the telcelor group) Includes at least four species: I. tmoolor, Io subeluta, I. sackeniana, and I. manshatte. These are characterized by the presence of a pale white area of varying length beyond the cord which gradually disappears as It runs into the lower portion of cell R5, completely through the cell Ist M2 and along either side of vein $\mathrm{M}$. The genitalis of this complex are very simslax to those of the freterma complex described below. The details of the genitalsa of this complex cannot be discussed here because I do not have avalable representatives of all the species. 


\section{Plate 1}

Figure 1. Genital structure of Iipula Iudoviciana as representstive of sayl complex. Fron left to rights outer dististyle, tergo-lobe, inner dististyle.

Figure 2. Genital structure of Mpuls furca as representstive of furca complex. From left to right: outer dististylo, tergo-lobe, inner dististyle. 
Plate I

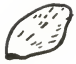
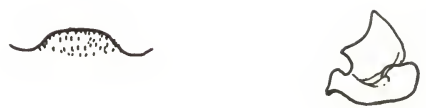

I

is
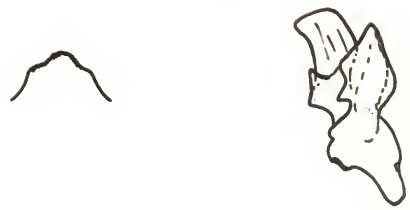

2

7 
There 1s, however, in the specimens available, some indication that this complex could be subdivided Into two lesser groups on the basis of the presence or absence of pencils of setae on the lateral mergins of the tergo-lobe.

The fraterna complex was considered by llogers to be one of the more difficult in which to deternine the valldity of the species. In this complex he included I. strepens, T. celopteroides, I. fraterms, I. Floridensis, and I. paculipleura. Along vith these described species several other specimens had been colllected through the jears which definitely belonged to this complex but whose affinitios with any of the described species were difflcult to detervine. Both Alescander (1942) and Rogers (personal comanulcation) questioned the validity of calopteroldes, saying that it probably was only a variant of strepens. In addition, Hogers proposed the possibility that with a large enough ceries of atrepens and fraterna avallable for study the differences between the two might be shown to intergrade completoly. I. fraterns, Ploridensis, and maculipleura were possibly conspecifio, being instead subspecies, or the results of many overiepping olines radiating out of the north and Appalachian areas. With these factors in mind, it was decided that extensive collecting in the southeastern United States might well shed light upon the speciation of the fraterns conplex and related conplexces as well. The wing pattarns of the varlous species within this complex vary but have, in common, the pale whitish pattern extending transversely along or just before the cord of the wing from the stifenal area to the base of the wing and Into the colls M3 and 14h. The differences of the genitalia of the specles of the fraterna complex are nearly 
negligible, or were thought to be so by Rogers, and will be described In detall later. I. strepens and calopteroldes have, in addition to the above, whitish areas in the Inner portions of the cells $\mathrm{n} 4+5, \mathrm{n}$, and M2. Other spectmens of this complex were taken occasionally whlch were similar to fratema except for a pale white ares to be found in the cell R $4+5$. Rogers also collected specinens from the Mountain Iake region of Virginia shich at the time were labeled "gtrepens near fraterna" or "Iratorma near strepens," Possibly, for this reason, Rogers began to think that the two vere intergrading or hybridising in certain areas. I. strepens is a distinctly northern and Appalachian epecies, hovever, while fraterns was reported from both the north and the south.

I. (1.) Nloridensis was described by C. P. Mlexander (1926). The holotype was taken at Gainesville, Morida, and was thought to occur only in the southern portion of the southeastern Unlted Statea. Mlexander described $\underline{I}_{\text {. }}\left(\underline{Y}_{0}\right)$ maculipleure one year lnter from one specimen taken by Rogers in the mountains of Fentress County, Tennessee (Mexander, 2927). The holotype of Iipula frateme, described by Hermann Loew (1864) from Washington, D. C., has apparently been lost and has not been available Por study.

The remaining species of the tricoler group in the southeast are not easily placed in any of the above complerses. I. ( $\underline{Y}_{\text {. }}$ concava possesses a wing pattern close to that of some specimens of stregens, but the sise, and especielly the characteristicg of the larval forms, show that this species might belong close to furca. Details of the tergo-lobe separate concava from the other cormplesces as a very distinct species. Ifttle was known about the ecology, distribution, and Ife 
histories of the species of the frsterna couplex, and It was decided therefore to add to the primary problen of the eystenatice as much information as possible about the biology of this ccuplex. 


\section{MINTODS AND MATERTALS}

In order to deternine the systematic atatus of the fraterna complex and the species within that conplex, more specimens and many more aspects of their blology had to be Investigated than had ever bafore been attenpted. In 1953, Dr. Iewis Berner of the University of Morlds received a Unsted States Public Health Grant for the purpose of studying the Mayfles of the southeastern United States, I vas fortunate in recelving an assistantship to help with this work, for 1t allowed me to collect cranaflies of the Iraterna complex at the same time. The eoutheastern states sampled weres Temnessee, North Carolina, South Carolina, Georgla, Loulsiana, Alabana, Mississippl, and Forida. The total mileage traveled approxdmated fIfty-two thousend wles, with about four hundred and twentymone collections made, of which one hundred and twelve resulted in the collection of some seven hundred and sixty-eight specimens of the fraterna conplex. The areas in which collections and observations were made are shown in Figure 3.

Approxdrately one bundred and aixty-four apecimens of the fraterna complex were also received from the University of Michigan Museun of Zoology through the Kindness of Dr. T. H. Hubbell, who also allowed me to use the late Dr. J. S. Rogers' notes on the fraterna complex, the main portion of which was distributional data. Dr. I. I. Townes also donated several specimens of this complex from the vicinity of Greenevile, South Carollna. 
Occasional specimens of the freterna or other conplexces of the tricolor group were also obtained from many of the colleges and universities of the southeast visited during the course of this investigation.

When collecting along a stream, I took every possible adult specimen of the fraterna complex present for a distance of approxdmately one hundred yauds in order to determalne the mubers of individuals present at a particular time along a particular stream. To better understand the ecological and texconomic reletions in one population, I concentrated my efforts in one strean at various periods in the vumer of 1956. This stream, located about six miles south of Chattahooches, Morida, is called Fat Creek. The serlos of specimens collected there are roferred to henceforth as the Gadsden County series.

Adulte were collected with a sweep net and kdlled in cyanide bottlee or preserved in alcohol. Those placed in cyandde jars were transferred to mell druggists' onvelopes (No. 3) and allowed to dry in this manner with the wings folded back over the body. Mduits to be leept alive were placed immediately in plastic containers $\left(31 / 2^{n} \times 31 / 2^{\prime \prime}\right.$ $x 21 / 2^{4}$ ) which were then put in a portable 1ee-box until such time as the specimens could be observed for varlous behavlors or could be used for obtaining eggs.

Observation of the adults was much improved by the use of a screen cage (20" $\times 16^{\prime \prime} \times 18^{\prime \prime}$ ), so construoted as to allow a large flat pan of water for malntaining high mulidity to be placed in the bottom. Many tines a large piece of clay with attached vegetation from the strean benk was also placed in this pen for watching oviposition behavior of the fervele. The lighting was kegt at a minimum when the cage was used 
indoors. The adults were then watched to determine their normal behavior. After observation, the femeles were elther preserved or egge obtalned from then, The males wore preserved as described above.

Two methods were used to obtain fertilized aggs. The flret was to place the feasale in a vial containing a little water so that the abdomen was imersed. This condition often stimulated the female to oviposit into the water. The other mothod was to remove the head of the female with a very small, Iine peir of scissors. This operation was done with care so as not to damage any other portion of the insect. When the fanale was dannged in such a way as to tear out portions of the nervous or digestive systens from the thorax, no egge were reloased. However, if the head was removed properly, the female, in a fow ulnutes, began to 2ay eggs. The reason for this activity may be explained by the presence of an Inhibitory action of the brain upon the ovipoaitore, but when the brain is renoved, the valves of the fomale are activated (Wlgglesworth, 1950).

The secont wethod of obtalning egge was decidedly preferable to the first. As many as one hundred and twenty eggs could be obtatned from a single fenale by the decapitation method, while only a fen to perhaps a dozen could be obtained by the other method. The more frequently the fenales mated, the easier oviposition occurred, and the larger the murber of fertilized ogge produced. I found that teneral females do not respond to either treatment.

After the oggs were lald, I placed then in one or two situations depending upon whether I wanted only the ogg and early stages up to and Including the first instar larvae, or whether I wanted the larvae to 
contimue their development. When put in contajners with clay, particles would stick to the chorion of the egg blocking observation of 1 ts development. Madimal vialbility in viewing the developing egge was obtained whan the egge vere put into contalners supplied with about an eighth of an Inch of water in the bottom. A small piece of clay was added to groups of the eggs which were to hatch, and larvae vere allowed to contime their develogment. This procedure was initiated, when as a reault of trensfer from containers supplied only with water to those containing clav, many or all of the recently hatched flrat instar larvae would dle. For some undeterialned reason, when the clay was added bafore the eggs hatched, the Iarvee 21ved. Specinens of the desired age were preserved in $F \cdot \Lambda_{\text {. }}$. or in 95 per cent alcohol. The advantage of the former was that if sectroning vere desirable at a future date, the speeinens would be suitably preserved.

Collecting the immature stages in the fleld was restrieted, by necessity, to the second, third, fourth Instar Iarvae, and the pupae. The eggs and first instar larvae were too gmall to be ceught by the strainer used to wash soll of the habitat away from the spectnens. If not preeerved, the larval specimens were placed in containers along with clay, moss, and Liverworts from the habltat. Inough water was added to danpen the soll thoroughly, but not saturate It enough to make It fall apart. If too much water was added to the containers, the larvae would climb up the sides of the eage and eventually die. This was espectally true of the flrst, and sometines of the second, Instar. The later Instars are also affected by the presence of too wuch vator in the rearing containers, but they did not die as readily under such conditions. A 
large supply of food materlal (clay and contained naterials from the habitat) was mede available to the larger instars. If enough food was not present, the uevally detritus-eating larvae turned cannibalistic, danaging or eating the other larvae within the eage. Usually no more than four of the lest instar larvee vere pleced in any one container at the same tine.

The pupae were always reared away from the larvae in the containers because they too would sometimes be attacked by the larvae. Pupating larvae and fully formed pupae were reared in two manners:s by plecing them on molstened paper, or by placing thern in a cage with a small anount of damp soll in 1t. The advantage of the forraer method was that It resulted in lreeping the exuviae or pupal case clean and free from particles of elay, providing better study spedimens. The advantage of the second method was that it showed the nore normal position of the larval exavise near the pupa, and that the beherior of the pupe in its natural onviroment could be more readily observed. Pupating larvae were separated from all other individuals so that the exurise from the last larval molt could be preserved, ss other larvae when present would almost imnediately consume the cast off skin.

The only way in which the genital or wing structures could be viewed in detall was to mount then on microscope slides. The genstelle were treated by first imnersing the detached terninal seguents in water to which had been added a trace of detergent as a wetting agent. The specinen was then pleced in 20 per cent sodium hydroxide solution and allowed to stand until the tissue had been dissolved. The genitalis 
were then washod in water and placed in glacial acetic acid. After fifteen to twenty minutee they were trensferred to a solution composed of one part of clove oil and two parts of glacial acetic acid. After an additional twenty rifnutes, the specimen was again tranaferred into another elove oll and acetic aold solution, composed of one part of each. The specimen was left in this solution until dissected and mounted on the slide. Duparal was used as the mounting mediun. The wings were processed in much the same as as the genitalla, but the step in which the specimen was put into the hydroxdde was onittod. The hydroxide made the wing too soft to work with and, in addition, caused decoloration of the wing pattern. Decoloretion was espectelly to be avoided as it is one of the characteriatics under study in this conplex. The right wing and the genitalia were mounted on the same slide. The genitella were oriented with the tergo-lobe and the left side of the ninth segment laft intract, the right side with the outer and Inner dististyles completely separated. The efighth sternite and torgite vere also included on the slide as were the eedeagus, the basal bulb of the penis, and a large U-shaped structure, discussed in the section on the norphology of 9. fraterna.

Nost of the structures vere measured by the use of an ocular micrometer. The nithth tergo-lobe was outlined by use of a canere lucide and lines drewn along the sides until they met. The angle formed was then measured with a protractor. 


\section{GROGRAPHIC DISTRIBUTIOA OF THS COAPLFXES}

The geogrephic distributions of the complexes within the subgecurs Iamatotipula which are closely related to the fraterna complex are shovm in Figures 4, 5, 6, 7, and 8 ; however, as there still remeins sone question concerning certain boundaries, particulariy the western extension of these ranges, these distribution maps must be coneidered as only tentative.

A look at the distributions of the varlous complexes may shed some light on possible trends in the fraterna complex, such as the eenter or centers of distribution, and also give further evidence of the relationship of thts complex to other complexes and, conseguently, to the apecies involved.

The earf complex has been found in the entire eastern portion of the United States and as $\rho$ ar vest as Arkansas. The couplex is represented by one species, I. Jamaicensis, in the Greater Antilles.

Menbers of the fucen complex are found as far westward as New Yexico, where Meccander (29l6) reports the occurrence of $I_{\text {. }}\left(\underline{Y}_{0}\right)$ Hicina. I. (1.) furca is found In Texcas and Missourl and into northern Forlda. The northern linit of all opecies in the complex is southeastern Canada. I. (1.) eluta has not been reported outside of the geogrephic 21mits of the two other species. The southern range of the furca conplex can now be extended into the mid-central peninsula of Florida, as I have taken gpecimens of furce from there. 


\section{Plate 2}

Flgure 3. Kap showing areas collected in southeastern states. Figure 4. Distribution of sayiconolex. Figure 5. Distribution of sures complex. Mgure 6. Distribution of caloptere complex. 
Plate 2
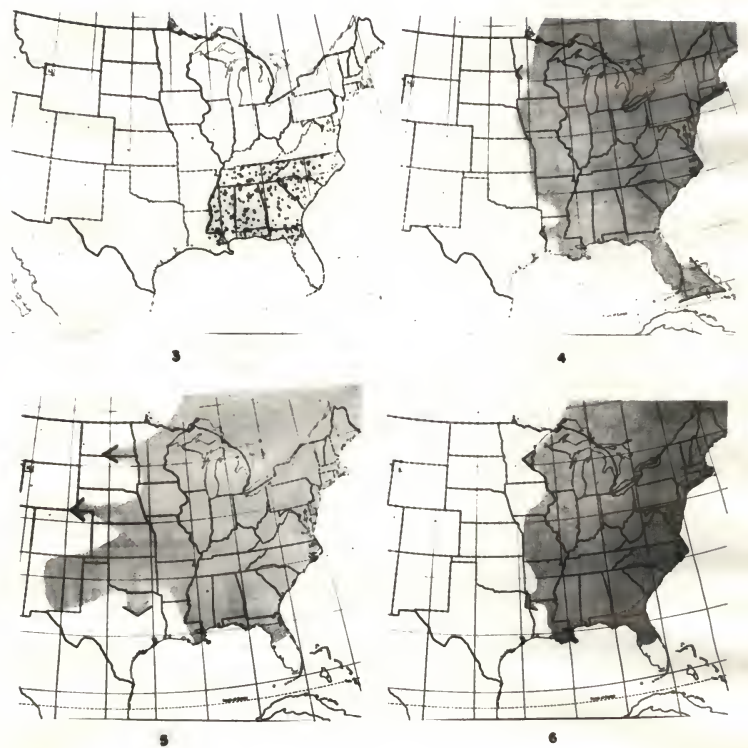
Plate 3

Figure 7. Distribution of tricolor conplex. Mgure 8. Distribution of conceva complex. 
Plate 3
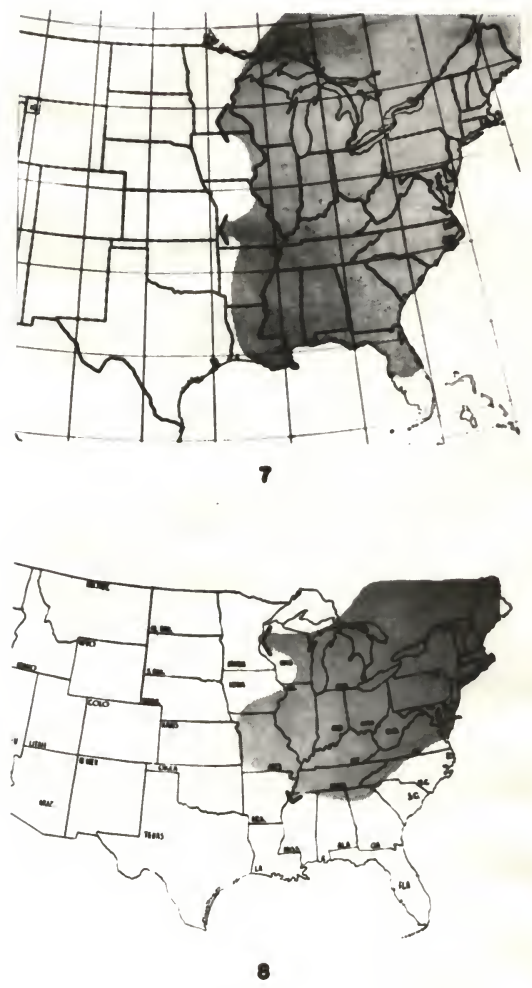
The caloptera complex is widely distributed, ranging from southeastern Canada in the north, Missour. In the west, and certainly as far south as the Weekdwachee Fiver in Mordda. Other specimens of caloptera have been taken in abundance in southeastern Louisians. $\underline{T}_{0}$ (I.) noveboracensig has not been reported previously south of Karylard and only as far west as Ohio (Foote, 1956). Subsnquently, a single specimen has been reared from a larva collected in the mountains of North Carolina. The range of the tricolor complex, based on records reported by Alexander (1942), extends Into Labrador in the north and Foride in tho south. The westorn range is known to extend at least into Arkansas, and I have taken I. tricolor, of 'd Porn) closely related to it, in southern Louisiana and Missiesippi.

The geographic distribution of the concare couplex covers the loast area. Hogers, in a personal communication, sald that this species had not been taken farther south than Tennessee and South Carolina. I have taken many specimens in northern Mlabome and northern Georgia, but not south of the Piodmont. Nlexcander (2942) states that this spectes occurs in Kissours and glves Its northern range, based on his records, as Connecticut and Michigan. The northern range wdll undoubtedly be extended into the lower portion of Ontario on the basis of the lanorm distrlbution of a plant, Justice americana, the roots of which Plogers (1930) states compose the "typical and almost exclusive habitat of this species." This plant grows along the sides of the rivere and in shallow streens Irom Texcas to Cunadn (Fernald, 1952).

The folloving changes in the taxconony are introduced here for elarification, but will be treated at greater length in the section 
entitled "Taxonony of the Mipula fraterna complex":

$$
\begin{aligned}
& \text { T. } \frac{\text { Doridensis }=\text { I. fraterna }}{\text { T. maculipleura }=\text { T. frateme }} \\
& \text { T. confraterns, new species }
\end{aligned}
$$

The fraterna cornplex is found in the eastern part of the United States. The distribution of strepens is definitely northern, the species never having been taken south of North Carolina (Alexender, 1941). Alexander (1942) also reports this species to be in the northeastern United States and southeastern Canada. The western lindit is reported to be Wisconsin and Kansas (F18. 9).

Mlexander (1942) reports I. Praterne to be found In New Henpshire, Connecticut; and Permsylvania in the north; with the southera range in Georgia and northern Morida. Rogers (1942) reports it in Kichigan and In 2933 in Tonnessee as I. (Ii) maculipleuxa. I have taken speoimens of fraterns in every state of the southeast, Including Temesseo; Kississippl, Loulsiana, Alabama, Georgla, North Carolina, South Carolina; and Forida.

The northern and vestern limits of the range of Mpula fraterne are poorly lenown, and I shell, therefore, concern myself only with Its southeastern distribution. The distribution of fraterns and confraterna Sollows, to a large extent, the Pledmont of North Carolins, South Carolina, and Georgia, following the Apalachicola or Chattahoochee river syotem from the Piectuont into the western pan-handle of Florida and fron there Into the north central and contral portions of Forlda, Leaving the ontire Coastal Plain area from eastern North Carolina, South Carolina, central and eastern Georgia, and northeastern Florida unpopulated (FIg. 10 ). flogers (1933) belleves that one of the major barriers preventing 
24

northern apecies of Tipulidas from spreading into the Coastal Plains of this area is the lack of "clear, fairly rapid, pobble-botton stroans," and "the scarelty of persistent, cool, molst shade . . .," nsually afforded by hardwood format1ons. With the data I have now, I can see no other explanation for the limitation of $\mathrm{T}$. fraterna fro: this area. Rogers (1933) also indicates that the gpread of northern species of craneflles into Morida via the Apalachicola River systen could be exw plained by the close sirilarity of ecologlcal conditions of this area to the Pledmont areas.

I have not taken fraterna in the northeastern part of Florida nor in the southeasterm portion of Ceorgis even after several trips to that area, and I doubt that the species lives in this region at all. Bellav (1947), in a careful study of the Tipulidae of the University of Morida Conservation Reserve at Welaka, was unable to find ang specles of the freaterna complex.

I. fraterna has not been found wouth of Marlon County, Moriria, where it was reported by Bellamy (1936). I have not taken it south of Alachua County. 11though there are numerous lakes and swamps in central Fortda, there are few peronnial aurface stream (Anon., 1938). The lack of these streans may account, at least partially, for the absence of 1 . Iraterna from this region.

The southem Iinit in southeastem Iouislana, MIssissippi, Alabama, and west Morida, parallels closely the beginning of the Interzonal soils, which typlcally are considered poorly drained (PIg. II). The western linits of the range stop parallel to the beginning of the Missiosippi-hlluviel solls and, to a lesser degree, the Hemphlsarenada 


\section{Plate 4}

Flgure 9. Distribution of Tlpula strepens. Iocallties fron which specimens were studied are indicated.

Pigure 10. Distribution of Mipula fraterna. Localities from which specinens were studied are indicated. 
Plate 4

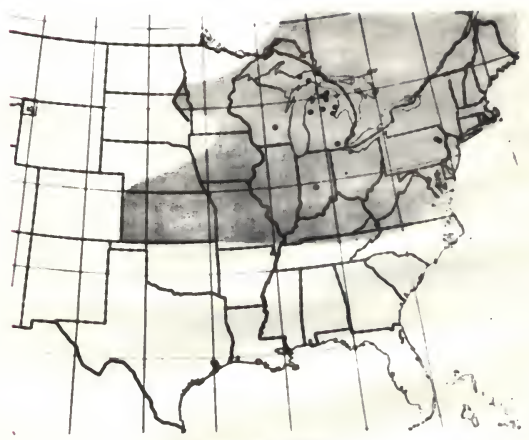

๑

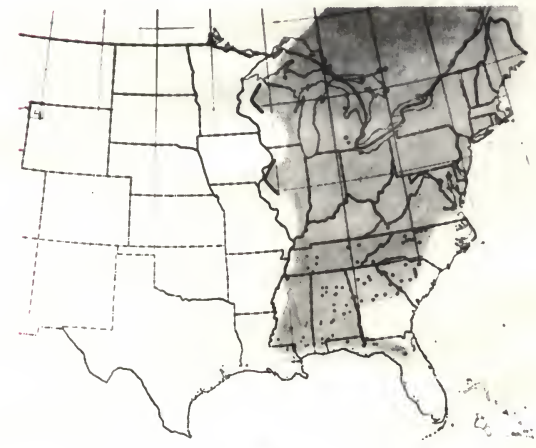

10 
so11s. Collecting was extrenely poor in this region. The streams are predominantly internittent, and those which are not do not possess sultable banis or over-hanging vegetation for immeture or adult stagen of T. Iraterna. In Tennessee I. fraterns was found in few of the streans near the Missiesippi, as most of them were dried up or canalised.

This distribution would appear consistent with the hypothesis that fraterna has a northem center of dispersal. If we look again at the distribution of the species complexes, we find that every speeies within these complexces occurs in the north. The tricolor group as a whole glves evidence of a northerm center of dispersal with the specles spreading to the weat and to the south. The distribution as a whole then would give further evidence of a migration of the fraterma complex southarard.

Records of $I_{.}\left(X_{0}\right)$ confraterna reveal a distribution very sintlar to that of fraterna. Specimens of this gpecies are In the University of Michigan Museun of Zoology collections from southern Kalne, MLhigan, northerm Indiana, southern Chlo, and Florlda. I have taken eppecimens in Tonnessee, North Carolina, South Carolina, and Alabane, Several spectmens were also acquired fron collections made by H. T. Towmes near Greenville, South Carolina. Iocations from which specinens have been colleoted are shown In Flgure 12 


\section{SBASONAL DISTRIBUTION}

The seasonal distribution of $\underline{T}_{0}\left(\underline{Y}_{0}\right)$ fraterns in the eastern United States varies considerably from Morids to Kichigan, repreaenting the southern and northern parts of the range. At Mlat Creek near Chattahooches fraterna begins to energe in the middle or latter part of March. Where adults occurred, the number obtelned per one hundred Jards of collecting was between three and $\mathrm{I}$ ive. By the riddie of Kay a maximal population was reached. The number of adults taken at Flat Creek at thils time was the highest taken anywhere in the southeest, numbering fortymone adults per one hundred yards. During the sumer, a low level was noted during the month of July, when about seven adult apecimens per one hundred yards were taken. The early part of August again showed a peak population, as shom by a collection of twenty-seven adults per one lundred yards. By the latter part of October, no specimens were taken from this area. The deta from other collections from Alabema, Missise1pp1, end Ioulsiane east of the Mississipp1 River follow: this trend with sone, but little, variation.

North of Alaberse seavonal emergence seans to be the sane as that found in Michigan. In Ternessee fraterne does not emerge until late Nay or early June. After the month of June, no advits were collected In most of the state. In meny places, however, larvae which corresponded to the age one would expect had the eggs been lafd in June vere found; but none were collected whioh would show a later suaver energence. Only 
In the southeastern portion of Tennessee were adults taken in the middle of Augrat, but then only in very amall mumbers.

In North Carolina the appearance of fraterns is nearly the same as that in Tennessee, but the emergence extends throughout most of the sunumer. However, the mumbers of adults taken numbered less towards the and of the sumner with no definite peaks occurring after the spring or eariy surmer emergence. In most streans the population peaks were quite abrupt. In sone streans I collected from fifteen to twenty adults per one hundred yards and later, within less than a week, found prectically no adults present at all. Bogers (1942) reports that only one generation per year is found at areas near the $\mathrm{\Sigma}$. S. George Reserve in Livingston County, Wichigan. The emergence took place there during the early part of the month of June. Alexander (1942) records the appearance of fraterns only in the months of June and July.

The sixty-degree isothern (Kincer, 1944) agrees favorably with that area in which I consider the periodicity of emergence of I. fraterna to change. Generally, north of this Line, the Insects show only one maximal period of energence during the early suruser. South of this line (Figure II) there is a contimul emergence, corresponding to that described above. Berner (1950) states that, in general, specles of northern origin are non-seasonal in Morids. The fact that 2 . fraterne shows a similar behavior does not disagree with the hypothesis that $1 t$ has a northern origin and center of dietribution and mas be considered to be added evidence of this phemomenon. 


\section{Plate 5}

Figure 11. Map showling so11 grougs, fall-21ne and $60^{\circ}, 65^{\circ}$, and $70^{\circ}$ Isotherins. (Adepted Irom Iearbook of Agriculture 1938, 194,

(A) Mississippi alluvial so11s, (B) Interzonal s0118, (C) Norfolkiblanton so11s.

Figure 12. Distribution of Tipula confraterna. Localities from which specimens were studied are indleated. 
Plate 5

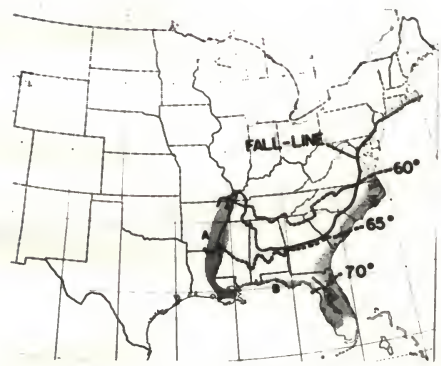

11

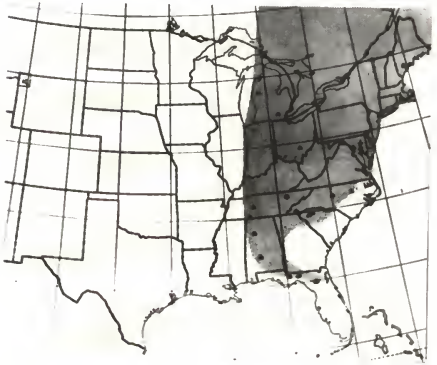

12 


\section{HABITAT REIATIONSHIPS}

The habitat of adult Fipula fraterna has been described brierly by Rogers $(2930,1933,1942)$ as being confined to streams. This restricted association has been confirmed by ny collections. For the habitat of the larval stages, Rogers (1942) noted that, "the larvae of what appears to be the same specles have been taken from submerged patches of filanentous algae in sund botton brooks in northern Florida,"

The fact remalns that prior to this study no investigator had made a definite association of the imnature stages vith the adult of Tipula Praterna. The larvae of T. Praterna were never taken by me in any aquatic situations such as reported by Rogers, and I an sure that the larvae of which he wrote wal another tipuline, but perhaps still within the tricolor group. Indeed, in areas such as he described, I have taken a tipuline larva, probably the one to which he was referring, altogether different from those of the fraterns complex.

In correlating the type of stream and strean bank with the occurrence of T. fraterna, the following characteristics vere considereds intermittance or permanency, rate of flow, pH, color, wldth, depth, slope of the bank, soil, and regetation of the bank.

Intermittent streans are conmon in the western parts of Mississippi and Tennessee. Streams in which water had very slow or no perceptible flow along the major portion of their course were considered stagnant. AII others examined varled in having a slow but steady Now, a conanon type In the Coastal Plain, to the cascading streams in the mountainous areas. 
The beds of streans in which Tipuls fraterne occurs range from sand-bottom streans, common in the Coastal Plains, to the rocky-bedded streans of the mountains. This character, while important in describing the habitats of other menbers of the tricolor group, has little importance with respect to the fraterns complex.

The most favorable type of stream bank has an almost vertical slope from the water surface varying from a few inches to several feet. Tipula fraterne seldon oceurs on benks which have a very gradual slope. The so1l of the bank in which the imnature stages occur is red-yellow or brown-yellow clay loan. The eggs, larvae, and pupae were not found in banks composed largely of silt or sand.

The strean banks whore $\tau_{0}$ Iraterna occurs might be considered as ecotones, because they have transitional eonditions between strictly aquatic and terrestrial habitats. Many of these stream banks are divisible Into three leyers or sones, which grede into each other, but which, for the purposes of deseription and discussion, will be considered here as distinct.

The first or lowest zone is closest to the vater aurface and has the most soll water as shown by the slight film of water on the clay. Thls layer is usually without macroscople vegetation, although there are occasionel patches of mosses and liverworts present. The root systens of the overhanging vegetation are partielly exposed with some olas adhering to them. Erosion of the bank in this lejer may be so great as to cause extrene undercutting of the bank forming a cavity behind the exposed roots. The roots below the water line may be well-washed or with a fine silt collected in then, but this was generally found to be a poor 
craneriy habitat.

The second zone is oharacterized by an abundance of mosses and Iiverworts. It may contact the water when the Plret Iaver is misaing. It is relatively more stable than the IIrst laver and resists periodie flooding and exosion. The soll is held tightly together by roots so that It is extrenely diffleult to wash out the larvae. The comnon mosses found

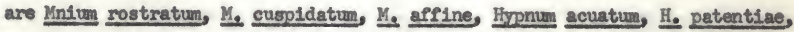
H. curvifolium, Plaglothecivm micans, Sphagmun palustre, S. subsecundum, Thuidium dellcatuluan, and Bryus sp. Some comnon liverworts are Marchantia sp. and Pore2la sp. Byers (1952) reported that specif1c Bryophytes were Important food raterlals and indicators of habitat noisture content suitable for species of Dolichopeza. I have found no correlation of $I_{0}$ fraterne larvae with any particular species of moss, and, if there is any ingortance to be atteched to the presence of Bryophytes with these Inxrae, it would be al Indicators of stability and suitable molsture content of the bank.

The thind layer of the strean bank includes herbaceous plants, grasses, and shrubs. This zone may be adjacent to the vatex surface in the absence of the first and second sones, but this condition rarely occurs. Generally, this wone is drier than the other zones. A plant conemon to this sone, especially in the Pledmont and mountains, is yellow root, Xanthorhira simollicessima. Vines, such as sinilax sp., and specles of Hyperteun also occur in abundance. These appear much more comnonly, however, In the Pledinont and the Cosstal Plain areas as do members of the Panily Vitacese (V1tis sp.). In all areas pabus sp. and poison IVy, Rhus toxdcodendron occur. Sometimes trees form a part of this layer and 
influence its composition by shading. Among these, especially in the Coastal Plains, are Alnus rugosa, Cyrillia racemiflora, Cyratila sp., Magnol1s sp., Ilex sp., Betula nigre, Crataegus marchall1, and Ulmus alata. Many of the mountain streans have Rhododendron thickets and mountain Iaurel, Kalmia sp., along the banics.

Regardiess of the ldinds of trees and shrubs, the Ideal streen for

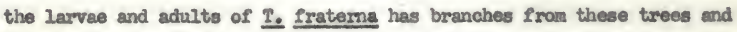
shrubs that arch over the bank and the water. The height of these varies, sose even touching the water's surface or dipping below it. These branches not only provide shade for the bank but also protect this ara fros the wind, rain, sun, and heip maintain a high humidity.

There are no apparent differences in habitats between $\underline{r}$. fraterna and I. confraterna, various stages of both occurring in identical situations. No larval specimens of strepens were found in habitats of 3 . fraterna in the Carolinas, although farther north they may occur together. However, I have not been able to verify this as I have not had the opportunity to vieit localities where I. strepens is known to occur. Mlecrander's (1941) description of the adult habitat leads me to belleve that they will not be found very far from I. fraterng in all cases where the ranges overlow.

The egge of Ilpula fraterna are latd in the first gone of the strear bank where they hatch into the fIrst instax larvae and are found here more counonily than in the second and third lajers. It appears that as the larvae grow, they extend thedr wanderings into the second and third lavere, where I usually found more third and fourth instar larvae. 
The larval stages rarely occurred in the third layer, and when I have taken them in this area, it has usually been after a hoavy rain. The rain makes the soil more molst, and the larvae would then move into this usually drlef. ares. Pupation oecurs in the seeond and thind layers, and no pupae were ever taken from the first laver.

There is no predictable distance from the water surface to the larval sites, but genersily ten to twelve inches above the water line is the uppermost 11mit. The presence of some of the mosses in this area, especially Sphasnum, Indicates that the water of the habitat is acid. The correlation of the distribution of $\tau_{0}$ fraterna and $T_{0}$ confraterne with the soil types in the southeastern regions also indicates that the golls have a slightly acld reaction. Larvae may sometines be found in the bank beneath the surface of the water, and I believe that the reason for this may be a audden rise in the water level so that larvae have not jet had time to move to drier soll. If larvae are left in contadners of . water for longer than a weok, they will become very alugglsh and PInally die, but if able to crawl out of the vater, they leave it and survive. Larvae may be found in barely molst soll on rare occasions, but are most abundant in soll which is damp. The larvee of I. freterna do not burrov laterally very far and are found no deeper in the banics than one to one and a hale inches. The spirecular disics cen often be seen extended to the surface of the soil. In some cased burrows can be seen which may have been made by other aninals as well as those made by the crenefly larvas and air is made avallable to the larvae through these open tunnals. An Interesting corollary to the stratirication of the banks is that one 
does not usually see these burrows in the sone nearest the surface of the water, probably because the larger larvae do not require the degree of molsture needed by the amaller larvae. This is probably because of the surfacemass relationship and the increased thickness of the integument, wilich means that there would be less vater loss from the surface of the larger forms.

Twe larvae in the rearing cages expel their fecal pellets from the clump of clay in which they have been placed. These fecal pellets are expelled with considerable force and land on the sides of the cage which may be as much as thres inches away from the clag. There is ovidence that this may be a protective measure to avoid pollution, becense larvae do not live as long in cages from which the pellets have not been removed.

The larvae of $\mathrm{f}$. fraterna have also bean taken from clay-ingregnated logs and branches partially lying the stream or neut to the edge of the clay bank. Larvae have never been taken at streams in which the banlas were conposed only of sand, as conap in northeastern Mlorida. Sone streams of the Atlant1e and Culf cosstel areas of the Cosstal Plain have banics with a eray to pepperwcolored soil contalning a large amount of humic materials, and larves have not been found in this type of bank. In streans with benks of cley, but which are barren and heve no overhangling vegetation, fraterna larvae or adults were not present.

Pupae of T. Praterna are found in relatively drier parts of the second or thind zone. Great numbers of pupel ceses can be seen in those areas just after the spring peak of emergence in the vicinity of Chattahoochee, Florida. The Larvae evidently work thenselves to vithin a fow 
ullimetere of the surface and then pupate, leaving the larval excuviae packed just behind. The pupee, Irmediately prior to emergence, go to the surface of the benk, anchor themselves by the gpines at the posterlor portion of the body and arch upward, lyling with the major portion of the body exposed. It is guite evident that with the pupe in this position the new2y energed adult, when stLll not separsted from the pupal case, will be helplessiy exposed to predators, as woll as to rain and wind. This condition probebly reduces the muber of surviving adults.

The adults are rarely found resting in branches over six feet above the water 11ne. Mpuls fraterna may still be found where there is no overhanging vegetation if something roplaces it, to malntain a high huridity and provide resting places, such as rocks jutting out over the bank of streams. On windy or reiny daye adults rest close to the surface of the bank and in the thickest portions of the overhanging vegetation. Iven so, rains evidently take s tremendous toll of the Insects. On several occasions I collected in streans which had a large population of fraterna one days the neat dey, after a heavy rain, few or no adults were found. 


\section{LIFE HISTORY}

The egg of I. fraterne would be ideal for the study of embryology of tipulids for two reasons: the egg is fairly large, and the chorion is pale yellow and nearly transparent making it possible to observe some aspects of the growing enbryo as development takes place. I am here considering that the time of oviposition is approxdmately the time of fertiIization. The totel period for larval develogment within the egg is from seven to ten days. Eggs from the same female, although lasd within five to ten minutes of each other, do not hatch at the same times, Nost hatch within one or two hours following the first hatching, but some will not hatch for at least an additional twenty-four hours.

Briefly, the embryonic development shows that at the end of the flrst twentym-four hour period, there is no noticeable change in the appearance of the egg. The end of the second twenty-four hour perfod reveals a contraction of the contents with obvious pulling awas from the chorion, especially at the ends of the egg. At the end of seventy-two hours, segmentation is noticeable on the doreal side of the embryo. Yolk material is collected in a ventral area, but segnentation here is vague or obscured. Indentations of organ buds are now seen at both the anterlor and posterior ends of the enbryo.

A red to dark brown spot forms on the anterlor and lateral sides of the enbryo between the fourth and sixth days. This area corresponds roughly to the darkened areas surrounding the ares of the flrst instar hesd caparle. By this time, the mouth parts have formed, but the 
mandibles are not hardened. Segmentation is visible, although the yolk wass is still noticeably large. During the sixth and seventh days the yolk mass diminishes in size; the dark areas occurring on the head capsule become much larger then before. During the elghth to tenth days the mandibles harden, and the head caprule becomes clearly derined.

Prior to hatching the larve eachiblts movement at its anterlor end. The posterlor end of the larve does not move at all or moves so little as to be hardiy discernible. The actions of the mandibles of the enclosed Larva are most striking - opening widely and then apparently seraping the Imer edge of the chorion as they close. The head capsule may be tristed so that the mandibles rest nearly dorsally or ventrally to the median lateral plane of the egg. The egg splits along the side opposite the micropyle which is here considered the ventral side. What ceuses the split is not known, although it could be partially due to the expansion of the embryo and to the scraping of the mandibles. As the larve emerges from the chorion it inmediately swelly to about two or three and one-hale times its size while in the ogf. This rapld expansion probably causes further aplitting of the egg. The larva then uses its mandibles to grip any available object and palls against the ege which is held in place by 1ts holdfast. By alternating the gripping of the object with its mandibles and contracting its entire body, the larve proceeds to pull itsele out of the shell and into the aurrounding soll. Sections show that yolk cells are still present in the gut of the newly hatched larva. These are evidently used up within another twenty-four hours, for sections of the day old larva reveel that the gut is now full of soil debris.

I have not been able to rear the first instar larva completely 
through the life oycle to the adult stage. From larvae collected in the field I was able to rear second instar to third Instar and third instar to fourth instar. First Instar larvae hatched from eggs in the laboratory have been carried through the second Instar during a period of thirty to thirty-ilve daye. Fourth instar Larvae were reared with oase to the pupal and PInally to the aduit stages.

During the larval molts a split in the integrment occurs dorsally and fust posterior to the head capsule of the exurise of the prior Instar. The new instar then proceeds to crawl. out of the old integument. The process of shedding the exuviae takes no more than a minute or two after the splitting occurs. The scarcity of exuriae from the various instars is due to the fact that they are eaten very soon by the new Instar or by other larvae near by. Byers also mentions this behavior in the genus Dollchopese and suggests that this may serve as one of the ILrst meals of the new Instar, serving also as a rich source of food materials.

A few hours prior to pupation, the larve becones very slugglah and weak. In addition, there are no typical larval movements, and pupal movement, a whipping motion, is now evident. The head capsule is pushed forward with the mouthparts pointing ventrally. Dorsally, through the Integument, the mesonotal breathing horns can be seen developing and ventrally the leg sheaths of the pupa are also seen forning. The lobes of the spirecular disk become soft and, Just before pupation proper, are enpty of any larval structure. In some specimens the tergal spines of the pupa were seen in the lobes of the spiracular disk, suggesting that these structures are homologous. 
At the time of pupation, the organism becomes slightly flattened dorso-ventrally and appears contrected, much like an accordion. The abdominal reglon sppears sl1ght2y inflated. The region of the thorax also Is the scene of rapid pulsating movenents. A split occurs just dorsel and posterior to the head expsule. The pupe then proceeds to move out of the larval exariae. The newly emerged pupa is pale yellow, the only derkened areas being on the mesonotal breathing horns. Hardening of the renainder of the bods is completed after four to 8 ix days. The wing pads are the last structures to achieve full coloration, the characteristic white areas in pupae of the fraterna complex occurring a day or two before energence of the adult. The time for pupal development takes from six to eight days at room tenperatures.

I have not seen the emergence of the adult of I. fraterna from beginning to end; however, I have observed individuels as they were nearly free of the pupal case. The coloration of the teneral adult is extrenely pale with a greenish tint. Byers has described the process of emergence for Dolichopeza, and I feel after having watahed other specles of the tricolor group energing from their pupal cases that the emergence of fraterns closely follows that pattern.

I did not feed the aduits as Byers reported doing, so I did not gather data showing the difference in longevity of the adult when fed as compared to that of the adult unfed. The latter period 1s, for $\mathrm{T}$. Iraterna, about three to four days, which is less than the expected Iffe span of the tipuline estimated by Rogers to be three weeks and by Byers half that for Dolfichopeze. I believe Byers' estimation to be the more nearly correct, based on my observations of $\underline{t}$ e fraterna. Byers found that 
adults when fod live half again as long as unfed adults, and preaumably the adults should live a little longer in their natural habitat then in the laboratory; tharefore, I feel certain that the life span of the achlt of I. fraterne is no more than ten to fourteen davs, and this only under ideal conditions.

Dogers (1933) reports that there are generally three to five instars in the larval stage of Tipulidae. Byers (1952) reported the possibility of pupal development directly from the thind instead of the usual fourth instar in Dolichopeza. I did not observe, or at any time suspect, that this behavior was happening in Fypula fraterns. There are four apparent instars in the larval development based on the leneths of larval boct and head capsule measurements ahown in Table II. The larval length was subject to variation in growth and age. The manner of preservation also affected length, but I foel that these measurements represent elosely the actual lengths of the insters. I assume that, due to the heavy ehitinsation, there is little or no growth of the head capsule during a perticular instar. The head capsule measurements are, in my opinton, the better guide to the deternination of the inotar. In oniy one case was there overisp between instars in the measurements of the Iarval body, and In this case a larva considered to be in the fourth instar was poorly preserved with a resulting length which would have laced it in the third instar. However, the hesd capsule definftely showed it to be within the range of the fourth inster group to which it properly belonged. The variation of the head capsule is conslderable in the last instar. This is also true of the larval length measurements. There was only a slight indication that the measurements of the head 
山4

capoule also indicate: the relative sise of the larval body. The largest head eapsule of the group measured was $2.08 \mathrm{~mm}$. In length, the larval body of which was $22.53 \mathrm{~mm}$, lang; the longest larve measured $28.08 \mathrm{~mm}$., and this specimen hed a head capsule measuring only $1.96 \mathrm{~mm}$. The smallest larvae of the fourth Instar grourp, measuring $16.80 \mathrm{~mm}$ and $19.95 \mathrm{~mm}$. , did have smaller head capsules measuring $1.53 \mathrm{gm}$. and $1.65 \mathrm{~mm}$. In length respectively. Byers states that in the genus Dolichopera the last instar takes the longest portion of the 14fe cycle, and that the second instar takes the shortest time. I belleve the same 18 also true of I. fraterns, which requires Irom ten to twelve months to camplete its life cycle.

The Exaphio representation of sizes of the imature stages is shown in Flgure 13. The number of Individuals neasured is shovn in parentheses and the extreme neasurements of length (In $\mathrm{am}$ ) are shown In Table 2.

\section{TABLE 2.}

LENOTHS DI MM. OF ALT STAGES OF I. FRATHEA AND LARVAL, HRAD CAPSULE LENGTHS

(Numbers of specimene measured are given in parentheses.)

\section{Bodir lensth Head eapsule length}

\begin{tabular}{|c|c|c|}
\hline rgt instar & $0.84=0.93(9)$ & \\
\hline at instar & $\begin{array}{l}1.51 \text { (just hatched) } \\
-4.52(10)\end{array}$ & $0.26-0.39$ (21) \\
\hline $\begin{array}{l}\text { Second instar } \\
\text { Third instar }\end{array}$ & $\begin{array}{r}4.69=7.20(8) \\
12.60=17.55(8)\end{array}$ & $\begin{array}{l}0.46-0.81(10) \\
1.02-1.35(13)\end{array}$ \\
\hline Fourth inster & $16.80-28.08$ (12) & $1.53-2.08(13)$ \\
\hline $\begin{array}{l}\text { Pupa } \\
\text { Adult }\end{array}$ & $\begin{array}{l}15.45-22.58(11) \\
14.00-27.00(10)\end{array}$ & \\
\hline
\end{tabular}




\section{Plate 6}

Flgure 13. Graphle representation of lengths of all stages of Tipula fraterna, larval head, cepsule lengths, and longevity of all stages. 
Plate 6

LENGTH IN DAYS OF STAGES

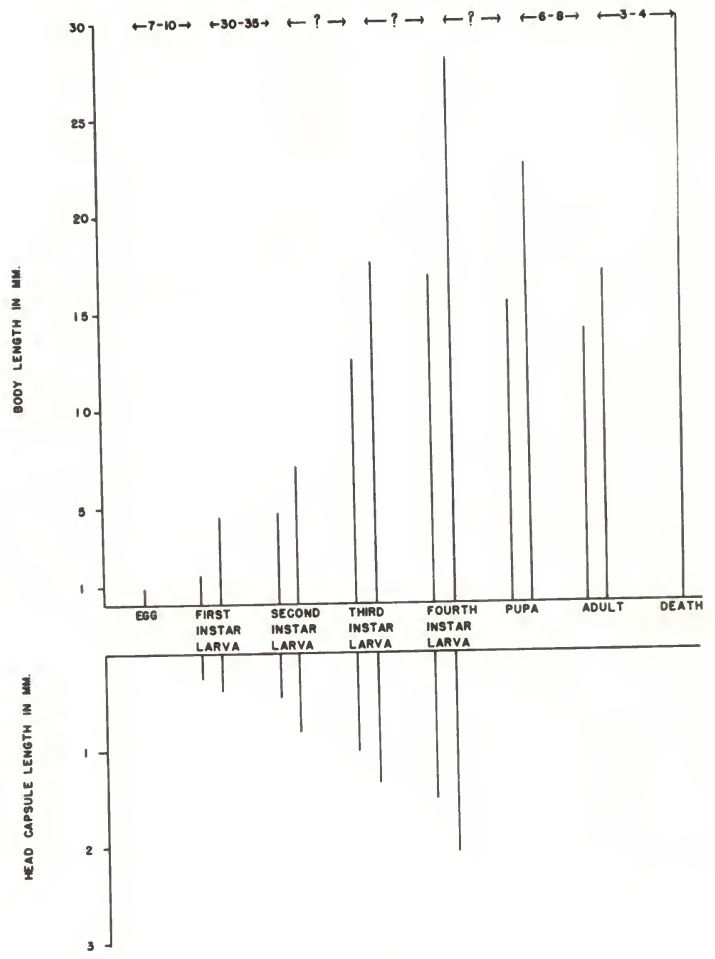




\section{MORPHOLOCICAL FEATURES OF THE ADULT}

The description of the morphology of the Fipula fraterne adult described belov includes only those structures used in the study of variation and the description of species within the fraterna complex. The following detalls are based on a study of specinens of T1pula eraterna. but may also serve for I. confraterne and I. Btrepens. Inclusion of a detalled moxphological description is not necessary here for the discussion of the apecies involved, and the differences that occur between these species will be mentioned in the section on the taxconcuny of theae species.

Male: The structure of the head of the male is shovn in Figure I $_{6}$ The major portion 1s occupled by two large compound ejes. S1ightly antorlor to the eyes is a pronounced ridge, the anterlor vertex, from whlch the antemae orlginate. The fronto-clypeal region is relatively ahort and stout, and the narus is 10ng. The anternae are composed of thirtien segments: scape, the pedicel, the eleven rlagellar segrents. The nouth-parts of the tipulid a re well described in Alexander (19/42), Crampton (1942), Rees and Ferris (1939), and Byers (1952). Byers clatms that Dolichopera hes four palpal segnents and a palplfer, or five palpal segments, while the other authcs report only four in Mpulidae. My observations agree with those of Byers.

In studying variability of the thorax, the most important atruetures to be considered are the episternum, the anepisternum, the sternopleurlte, and the propleurite, all of which have been adequately described 
by Alexander (1942). These structures are shown in FIgure 14. The Interpretation of the wing venation followed here is also that of Alexander (M1gure 15).

The male abdomen is characterized by the first abdominal segment being much shorter than the other segments, The second segment is between three and four times the length of the first and is the longest segment of the abdomen. The renainder of the segments become shorter posterlorif.

The ninth tergite is fused with the ninth sternite, but on the posterior portions of this sogment is a light area, which mey correspond to the pleural suture, Detalls of the hypopgrgiun, including the outex dististyle, Inner dististyle, aedeagus, sentnal bulb, and ninth tergo-lobe, are shown in Mgure 16, A, B, C, D, I. To facilitate the discussion of the functions of the various lobes of the inner dististyle, I have designated them as lobes $1,2,3$, and 4. The tenth segment has bean considered by other investigators to be the membranous portion surrounding the anal opening, an interpretation with which $I$ an in agreenent, In $I_{0}$ Iraterne there are two sclerotired plates imediately doreal to the anal gpening which may be reumants of the tenth tergite. There is some question as to what the U-shaped structure shown in Figure $16 F$ may be. It may possibly be referred to the opimere as described in Tipula reesi by Hees and Ferris (1939). Perhaps a more Ilkely possibility is that this atructure represents a vestige of the tenth sternite. The ninth sternite has at its anterior edge a thickened area, heavily chitinized. The structure in question might correspond to this particular area on the tenth sternite. The position of the structure is such that 1 ocours at 


\section{Plate 7}

Figure 14. Structures of head and thorex of Fipula Praterna.

$$
\begin{aligned}
& \text { ses - anepisternum } \\
& \text { - aye } \\
& \text { es - eplsternum } \\
& \text { n - nasus } \\
& \text { pn - pronotum } \\
& \text { pse - praescutum } \\
& p \text { - pedicel } \\
& s c \text { - scape } \\
& \text { spl - sternopleurite } \\
& V \text { - vertex }
\end{aligned}
$$

Mgure 15. Wing venation of Tipula Praterna.

$$
\begin{aligned}
& 0 \text { - costal } \\
& \text { cu - cubitus } \\
& \mathbb{M} \text { - medial } \\
& \text { Rs - radial sector } \\
& \text { R - redial }
\end{aligned}
$$




\section{Plate ?}
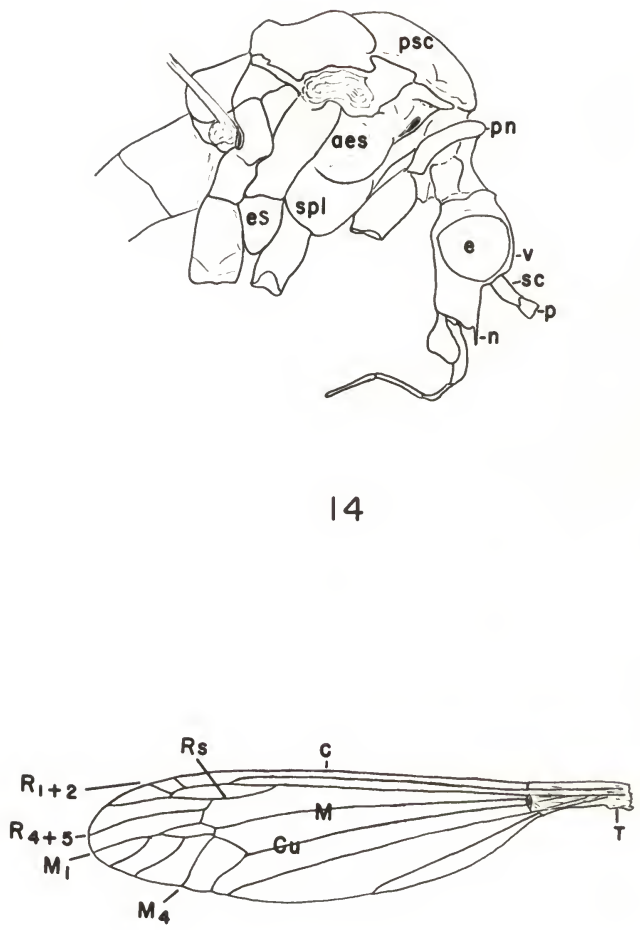

15 
the bese of a membrane which surxounds the anus ventrally and laterally and thus would correspond to the aree in which one would expect the tenth sternste to be located.

Female: The external norphology of the fomale agrees, generally, with that of the male except for shorter antennae and the genital aegments. The elghth sternite is now considered by most students of the Iipulidae to be projected into the hyporalves of the ovipositor. The ninth segnent is characterized by having a thin dorsal plate or tergite. Ventral to this plato a lobular ares occurs which is just dorsal to the gonopore. This area is strongly sclerotized and articulates with the ninth tergite, and so is considered to be the ninthsternito. Inmediately below and anterior to the gonopore is a long sclerotized blade which, in a Lateral View, ourves ventrally and, toward the anterior tip, again curves slightly dorsed. The posterior tip of this blade is compressed dorsomentrally and becomes much broader. Medtally on this broader portlon, there occurs a notch wh1ch gives the whole structure a I-shaped appearance. This correaponds to the I-shaped structure described by Byers in Dolichopese, that of $\mathrm{T}$. fraterns differing slightly in sise and shape from that of the former. Because of confusion in the interpretation of the morphology of the teminal segrents of the female, those up through the tenth have been labeled in Figure 17.

The region beyond the tenth tergite, 1.e., the cerel and a bilobed strueture beneath and posterior to the anus, is indistinct. The bilobed structure corresponds favorably to that structure marked as the tenth sternite in Tipula rees1 (Roes: and Ferris, 2939); however, those same 


\section{Plate 8}

Figure 16. Wale hypopyrial structures of Mipula fraterna.

A. Imor dististyle

B. Cuter distiatyle

C. Lobe of ninth tergite

D. Ledeagras

E. Sendnal bulb

T. U-shaped structure 
Plate 8

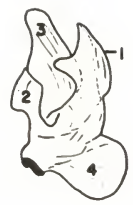

A

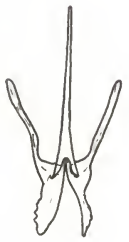

D

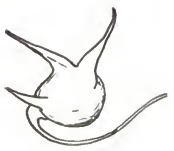

E

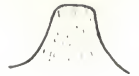

C

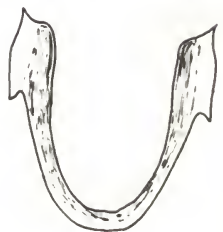

F

16 
54

vorkers have considered this structure plus the cerci to be structures of the eleventh segment in Iimonia sciophtla. 
Plate 9

Flgure 17. Penale hypopyglum. Segnents numbered through tenth. 
Plate 9

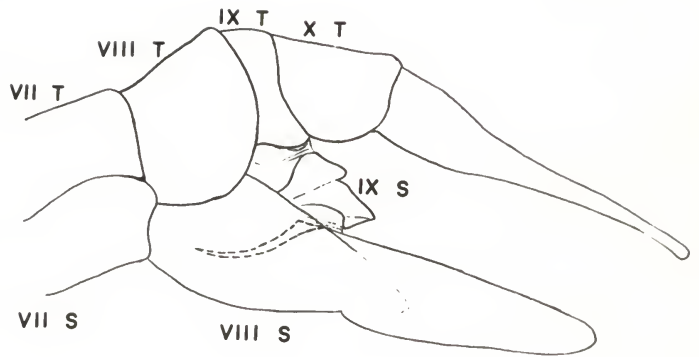

17 


\section{TAXONarY}

\section{T. Praterna}

The following characters show continuous variations which do not appear to have geographtcal significance, nor do they appear to separate Into a fraterns, floridensis, or maculipleure type, Some are also modsfled by conditions of preservation.

Loew describes the antennae of Tipula fraterna as being pele yellow with the apical segments somewhat brownish and the basal segments ha1ry. Alexander (1942) describes the antennae of I. fraterne as being relatively long and bicolorous. He also described the antennae of $\mathrm{T}$. Moridensis (Alexcander, 2926) wh the first basal segment dark brown and sparsely prutinose; the second besal segment a little paler; the flagellar segments bicolorous, with the long pedicel of each yellow, the besel portion darker. The distal flagellar segments are described as becosiling uniforwly brove or infuscated. Specimens of the Gadisden County series, and from the southeast generally, show that in coloration the antemse range from the second to the distal Plagellar segments being almost entirely yellow and Lightly bicolorous, to all segments appearing infuscated with the bicolorous condition nearly obliterated. In any case the bicolorous condition is not seen on the first or second basal segment and only vaguely if at all an the first flagellar segment. Ioew describes the rostrum of $\mathrm{T}$. fraterns as being pale yellov. Mlexander states that this is also true of $\mathrm{T}$. Ploridens1s. I have mans specimens 
from the southeast which show the rastrum as light brown. The palpl of the two species are considered dark brown by both investigators and, while not so stated by Mlexander (1927), those of T. macullpleura (holotype) are also brown. The coloration of this structure in the Gadsden County series and the southeast generally show considerable variation with yellow and brown ustures.

The head of I. Ploridensis is described as daris gray with anterior vertex paler and in the fonale with a eapillary medien vitta, Loew. also described such a vitta in the fenvale of T. fraterne which he used as the type. The males which I have exanined also have a dark nedian vitta in this ares; however, there is a gradation fram complete obliteration of this vitta, due to the dark coloration of the parietal reglon, to a distinct line running from the anterior vertex to the occiput.

The praescutal stripes have a sirilar degree of varlation, ranging Prom being distinctly visible to almost obliterated. The type of $\mathrm{s}$. maculiplenre is very discolored in this reglon but does show the presence of these stripes. In all areas of the pro-, mesom, and meta-thorax, the maridings of the sclerites vary in color from light to dark brownishjellow or brown. The only apparent character difference between I. Iraterna and I. maculipleura is in the characteristic coloration of the pleura. Alexcander separated I. paculipleura from I. fraterna and $I_{0}$ flortdensis by the occurrence of brovm maridings on the ventral half of the stemopleurite and on the anterlor portion of the anepisternum as well as the propleurlte. Thls condition can often be sean on specimens through the nomal amounts of prusnose materlal present. Even in the topotypes of ploridensis, faint suggestions of this condition can be seen 
on the pleura. These spots become very distinct as soon ss the pruinose material is matted or in some way neutralled by the various methods of relexing or preservation of the specimen, or by the 011s from the spec1mens themselves. I decided to see what would result by talding specimens at randow whilu wore preserved in alcohol and observing the spots vilich occur in these areas. In nearly all cases these spots showed through the pruinosity, and the apecinens would have been considered to be I. maculipleura. I also selected two specimens of I. fraterns which did not show the brovm through the pruinosity of these areas and subjected then to treatment in a relarding far and found that the same maridings became apparent. The legs of all the specimens also agree in range of coloram tion. Norrally the diatal and of the fenur has the tip dark brown, but sonetimes the coloration is ao intense as to obliterate this character altogether.

The abdominel tergites are dark brown on the sublaterel margins giving the insect the appearance of heving two stripes on the abdomen. These sublateral stripes may expand over the tergites until the dorsum becomes unicolorous, except on the second which remalns iighter. In view of my findings, I can see no veled reason for considering $\underline{t}_{0}$ maculipleure to be distinct from T. fraterns and I wh, therefore, placing maculipleure as a synonys of fraterna.

There appens to be no orderly distribution of these variations that would suggest geographical influence. Byers states that colorstion In the genus Dolichopeze must be used with extreme caution as a taxonomic criterion. This is certainly true withsin the fraterns complex and may apply to the entire tricolor group. 
Charecteristics of the fraterns cormlex which show suggestions of geogrephlic as well es population differences include features of the vings of both sexses and the genitalla of the males.

The wings and the genitalis of these spocies, as is genererfy true for the Ipulidse, play an Important part in the deternination of species in this complex. The unfortunate fact 1s, however, that Ioev did not describe the male of fraterna and the type (femele) has been 10st. Alexander and Hogers have buflt the concept of fraterns, floridensis, and maculipleura on specimens which occur in the north, in Florida, or in Tennessee. Rogers noted also that fraterne exists in Florida, along udth the species that he considered to be floridensis. One Florida population lonown to have both types was sampled by me for the major portion of a sumer in order to study the variation within it and to determine the validity of ploridensis as a species. I. floridengis supposediy had several slight differences separating it fron fraterna. The outer dististyle and the tergo-lobe differences were considered to be the most diagnostic. On the outer dististyle, two extremes were noted - the occurrence of a tuft of setae on the apical caudal edge of the outer dististyle in specirens considered to be good florldensis; the absence of this tuft or the even distribution of setae were considered as characteristic of fratema.

Five samples were taken from Flat Creek south of Chattahoochee, Morids of which one was eliminated because it was collocted within a fev days of another. I assuned, therefore, that any possible differences between the two samples would be nogligible. Adults that I might have missed in the first collection might possibly appear in the second 
collection, thus a distinct break between the two sarniles would not be present. Samples considered were collected on the folloring dates: March 30, Mav 28, July 16, and August 22, 1956. The collections were spaced more than a month apart so that adults allive at the previous time of collection would not be alive for the next sanpling, and overlap was thus avoided.

AII of these specimens wore dissected and mounted in euparal according to the method outlined previously. The outer dististyles were then classifled decording to three types. The flrst consisted of gpecimens whose dististyles were considered to be typical for fraterna, based on Inogerc' experience (personal cousunication) and Alexander's description of this species. This type is characterized by the even distribution of setae or the absence of a turt of setae on the aplesl caudal edge of the dististyle (Mgure 18). The Ploridensis type of outer dististyle was picked following Rigers' and Alexander's ldeas of Ploridensis plus a study of specimens which were newed by Rogers as Ploridensis. This type had a tuft of setse on the apical caudal margin of the outer dististyle (FIgure 19). The third type is composed of specimens whose outer dist1styles are gradations between the two extremes. All intermediates were assigned here. The results of the examinations of the Cadsden County series are shown in Table III.

Within the Individual samples the percentage of fraterna type Individuals decreased as the sumer progressed, while the floridensis type individurls increased in frequency. The internediate types tended to become progressivaly more numerous during the summer. The presence or absence of a tuft of setae on the apleal caudal edge of the outer dististyle 
may then be fire, in part, to seasonal differences and is not considered a valid character for separation of the two specles.

TABLE 3.

\section{PERCEYTAGE OR INDIVIDUALS FROM THE GADSDEN COUNTY \\ STRIES SHOWDNA FRATEREIA, FLORTDWNSIS, AND INTERATDIATE TXPS OF SETAF DISTRTBUTION OA OUTER DISTISTMRES}

\begin{tabular}{|c|c|c|c|c|c|}
\hline Type & March 30 & May 28 & suzy 16 & August 22 & TOTAZ \\
\hline Praterna & $n_{n=215}^{728}$ & $\begin{array}{l}59 \% \\
n=24,4\end{array}$ & $\prod_{n=1}^{14}$ & $\frac{228}{n-5}$ & ${ }_{n=45}^{48 \%}$ \\
\hline Ploridensis & $\begin{array}{r}5 \% \\
n=1\end{array}$ & $\begin{array}{r}58 \\
n=2\end{array}$ & $\begin{array}{l}43 \% \\
n=3\end{array}$ & $\underset{n=9}{37 \%}$ & $\begin{array}{l}16 \% \\
n=15\end{array}$ \\
\hline Intermediate & $\underset{n=5}{2145}$ & $\underset{n=15}{36 \%}$ & $\begin{array}{l}43 \% \\
n=3\end{array}$ & $\ln _{n=10}$ & $\begin{array}{l}36 \% \\
n=33\end{array}$ \\
\hline $\begin{array}{l}\text { TOTAL SPBCDMENS } \\
\text { II SAMPLE }\end{array}$ & 21 & 41 & 7 & 24 & 93 \\
\hline
\end{tabular}

$\%=$ percentage in each sample falling into this category.

$\mathrm{n}$ = actual number of specimens in each sample farling into a particular category

Table 4: shows the results of lumping thirty-three southeastern collections. It is interesting to note that if, in Table 4, I had merely luwped all of the specivens together without regard to month of collection the results could be interpreted as representing two species with a number of intergrades present. However, presenting this material in the same manner as in Table 23 , the data in Table 4 can be more correctly interpreted, 1.e., with the percentage of Ixaterne type individuals decreasing, the percentage of ploridensig type individuals increasing, and always some intergrades between the two extremes during the sumer. Table 4 Includes sanples from all states in the southeast. 
TABLS 4.

\begin{tabular}{|c|c|c|c|c|}
\hline & $n=1,0$ & $n=2$ & $n=7$ & $\begin{array}{l}39 \% \\
n=4,49\end{array}$ \\
\hline Ploridensis & $1_{46}$ & $40 \%$ & $72 \%$ & \\
\hline internediate & $\begin{array}{l}13 \% \\
n=?\end{array}$ & $\begin{array}{l}20 \% \\
n=1\end{array}$ & ${ }_{n=14}^{22 \%}$ & $\begin{array}{l}17 \% \\
n=22\end{array}$ \\
\hline $\begin{array}{l}\text { TOMAL SPECIMPAS } \\
\text { II SAMPLB }\end{array}$ & 55 & 5 & 66 & 306 \\
\hline & & & & 120 \\
\hline
\end{tabular}

Another fact, not shown in Table. 3, is that $I$ have in this population at least one individual which shows the fraterne type dististyle on one side and the floridensis type dististyle on the other side. The normel situation, however, is to have both dististyles alike. Because of the varlability, it seens useless to analyze a mean type of outer dististyle to be found in a particular locality in the southeast. To do this, summer-long sanules must be had from each location, and such samples are not available.

The shape of the outer dististyle was studied to see whether my condition in this structure used by Alexander and logers for systematic separation of the two aupposed apecies would be valld. This structure, along with that of the tergo-lobe, appears to have the greatest amount of variation of any of the structures studied. There also appears to be as 
much varlation within the Gadiden County series as is found in the entire southeastern distribution of T. Iraterna. The sane is true of the number of sette which occur on the tergo-lobe, a chexacter suggested by logers (personal communication) as a possible one for use in the separation of the species. The varlations in ahape of the outer dististyle were: (1) the width of the stem of the outer dististyles (2) the curve of the apical end of the dististyles and (3) the shape of the apical end of the dististyle. The width of the stem was indirectly considered by Rogers when he suggested that the shape of the outer dististyle was strap-like. This would, in ay opinion, Indieste a shape such as thow in Figure 20. I have found all gradations between this condition and the development of a bulge, giving an Irregular shape to the stem, as shown in Figure 21. The curve of the outer dististyle was also considered and again the variations were continuous and did not show the possibility of two species being present (Figure 22 and Figure 23). The shape of the distel and of the outer dististyle of T. Ploridensis was described by Alexander as truncate and by logers as having no aplcal cephrlo 10be. The shapes to be found in one of the aamples of the Cadsden County serles are shown in Plgure 24. Both lobed and lobeless dististyles were seen in all sanples. A condition of similar scope is seen in the shape of the distal. tip of the ninth tergo-lobe. One extrene has the tip almost taruncate, the other has the distal tip rounded. In both the outer dististyle and tergo-lobe, northern and southern specimens show sinflar variationa. Variation in size of the insect was also considered, but only in the Cadsden County series. The sempling was not cauplete enough for comparison of measurements of populations from north to south. Body length 
Plate 10

Figure 18. Setal distribution of fraterns type outer dististyle. style. Figure 19. Setal distribution of floridensis type outer distiFIgure 20. Strap-shaped stem of outer dististyle. Figure 21. Irregular sten of outer ditistyle. FIgure 22. Nearly straight outer dististyle. Figure 23. Curved outer dististyle. 
Plate 10

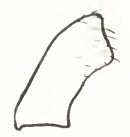

18

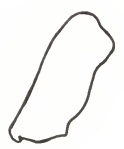

21

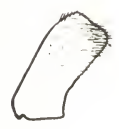

19

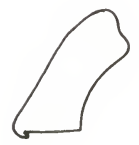

22

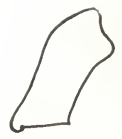

20

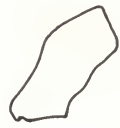

23 
and wing length are correlated, the larger the wing, the longer the body and vice versa. It was evident that the first three measurements indicate one factor alone: that the ving length and body alse change with the time of collection of the specimen. The fourth measurement indicates the variation to be found in the angle of the ninth tergo-lobe of I. fraterna. The measurenents are as follows: (1) The distance from the areurm (areual point) to the tip of the wing: the areual point is that point at which a depression in the wing is formed in the arcuvan. (2) The distance from the arcual point to the inner base of the tegula. The total of the above characters, (1) and (2), is considered to equal the spprossinate length of the ring. During the process of removing the wing from dried specimens the tegula was sometimes destroyed. For this reason both measurenents were taken, the first being more important to variation studies because of 1ts avallability. The changes during the sumuer, of esch, vere closely matched. (3) The length of the ninth tergite, measured along 1 ts midLine. This confirzed the conclusion that the body sise decreases from early to late surmer. (4) The angle of the tergo-10be. After mounting the tergo-lobe on a slide an outline draving was made with a canera Lucida. Lines were then drawn along the two sides of the lobe and projected unt1l they net. The angle was then measured with a protractor. The results are ahoum in Table $V$.

The means of the first character show that the relative size, as roflected in this structure, decreases as the sumer progresses. This condition is found commonly in many other insects and was reported by Byers to be true also for Dollchopeza. The range of the approxdinate wing lengthe for the wonth of March is 28.33 m. to $15.50 \mathrm{~mm}$. f for Nay, 27.67 to $14.72 \mathrm{~mm} .3$ for July, 16.41 to $13.24 \mathrm{~mm}$; for August, 16.11 to $13.86 \mathrm{~mm}$. 
กิ่<smiles>C1=C[Te]1</smiles><smiles>[CH]1[CH]C=C1</smiles>
ल

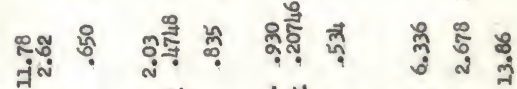

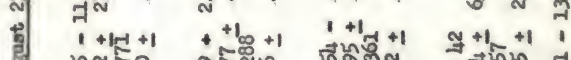

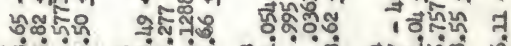
สभึ่

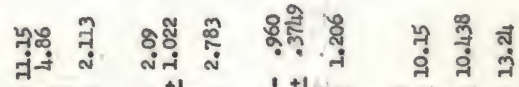
1) $1+18+1 \quad 1+1+1 \quad 1+6+1 \quad 9+1+1$ เ

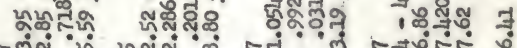

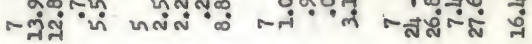

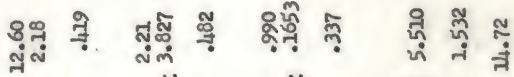

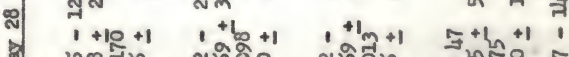

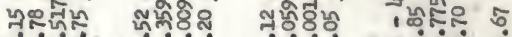

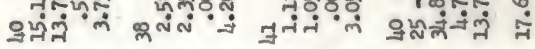

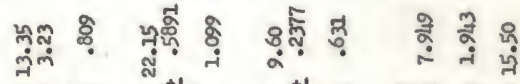

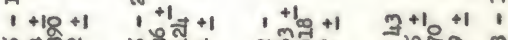

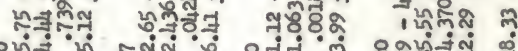

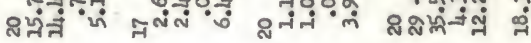

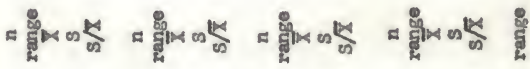
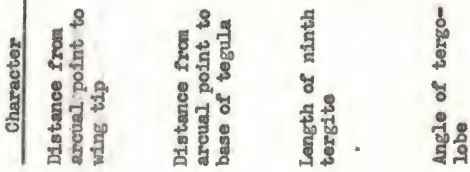

क्षे है 
The measurement of the angle of the tergo-lobe reveals that the range of means is 35.55 degrees at the begiming of the sumer to 31.04 degrees at the ond of the sumer. This measurenent also shows the highest coefflcient of variation of any of the meagurements. In other samples tested but not shown in the P1gure, this measurenent constantly has a much higher coefficient of variation than all other structures measured, varying from a coefflesent of nine to that of twenty-seven; the latter, was found in those speeimens of the Gadsden County serles. The data show that in the samples of this series, there appears to be an increase of the coeffleient of varlation as the avumer progresses; how ever, by computing the standard error and the standard error of the difference (Beder, 1955) and comparing the latter to the actual difference of the means as in an ... . . . ..., there was found to be no signifleant difference between the first and last samples.

The ahape of the outer dististyle, the presence or absence of the tuft of setse, and the angle formed by the sides of the tergo-lobe did not in any manner correlate, loading me to believe that two separate species were not present. I an, therefore, considering I. floridensis to be a symonym of I. fraterna.

It was realised that in order to understand the differences in color petterns present in the wings of species of the fraterne complex a basic color pattern must be recognized. This was accomplished for $\mathrm{r}_{0}$ fraterna by taking a sumer-long series of specinens to deternine the basic pattern. This pattern was then compared to other specimens within the geographie range being considered. Again the Gadsden County series supplied much of the information about the basic wing pattern, which is 
here described as that pattern in which whitish fascia always mpears along the cord and on the outer ving cells (Mgure 25). The sigure shows that portion of the pattern which renasing moat constant in shape throughout the sumer. The pattern consists of the pele whitish fascis extending from the stigmal area, along the cord of the wing, into the cells $\mathrm{M} 3$ and XI. Figures 26, 27, and 28 show wing patterns from the seme population with the aress of the distal portion of the wing which become very 11 ght and in some cases nearly white. The basle pattern remains unaffected. The frequency of these variations within the samples of this population during the summer is ahown in Table VI. Cells 23 and $\mathrm{Mh}$ always have the pale white fascia. The other colls possess lighter areas at much lesser frequencles. No change from this condition is seen in any of the sarmples within the southeast. In only one case the wing possessed a lighter or whitish ares in cell R3 along with 2ighter areas In cell $\mathrm{R} 4+5$ (Figure 29 ).

Table VI also indicates that the occurrence of a lighter arem in cell U2 is much greater than the occurrence of such areas in cells MI and R4 4 . The information suggests that the appearance of these 11ghter areas is genetically doternined, but it is also subject to ecologlcal influeuces.

The basic pattern also shows some variation within the southeast; however, there is no indication that a cline involving this character is present. The most striling variation of the wing patters within the southeast was found in two areas, one near the Alabame-Forida state line on the Little Bscambia River and in Stone County, Mssiseippi. In both cases the normal basic pattern was present in some specimens, but in others the pattern was nearly obllterated, merely belng suggested 
Pigure 24. Variation in distal tips of outer distiatyle of specimens of Gadsden County Series. (A) Mareh 30, (B) August 22.

Migure 25. Basic wing pattern of Tipule fraterna. 


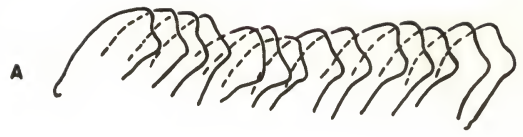

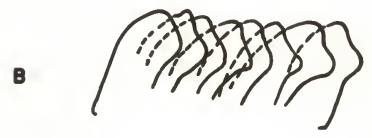

24

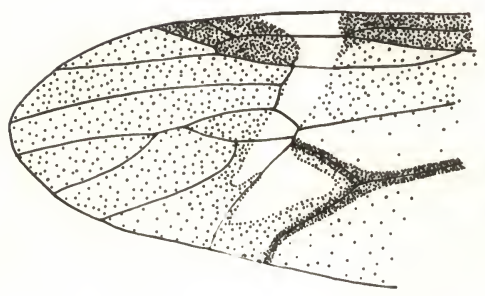

25 
within the cells M3 and M4 (FIgure 30).

\section{TABLI 6}

THE PERCENTAGE OF INDIVIDUATS IN GADSDEN COUNTY SERTES SHOWING WHITS OR LIOHI ARRAS IN WING CEHAS

Variation

White or I1ght

areas in cell:

$\mathrm{I}_{4}+5$

$M_{1}$

$\mathrm{M}_{2}$

$M_{3}$

$1 / 4$

TOTAL, NURBER OF

SPECTMENS EXANTIVID 20
March 30

May 28

July 16

August 22

$\underset{n=0}{0 \%} \underset{n=5}{12 \%} \underset{n=2}{29 \%} \underset{n=1}{4 \%}$

$0 \% \quad 27 \% \quad 29 \% \quad 48$

$n=0 \quad n=7 \quad n=2 \quad n=1$

$0 \% \quad 29 \% \quad 57 \% \quad 23 \%$

$n=0 \quad n=12 \quad n=4 \quad n=5$

$100 \% \quad 200 \% \quad 100 \% \quad 100 \%$

$n=20 \quad n=4, \quad n=7 \quad n=2 / 4$

$\underset{n=20}{\substack{100 \% \\ n=41}} \underset{\substack{100 \% \\ n=7}}{\substack{100 \% \\ n=24}}$

4124

Another type of varlation also occurring in the Stone County, Mississippi, sample is the presence of a spur on the angle of the vein is before it reaches the distal tip of the wing (Figure 31). This variation also is found in the Gadsden County serles, occurring near the end of the surmer, and found in about twelve per cent of the specimens. The Stone County population also was collected near the end of the surmer. These three regions were the only ones in the southeast in which varlations of this type were found.

1. confraterna

The basic ving pattern to be found in avallable specimens of $\mathrm{T}_{0}$ 


\section{Plate 12}

Figure 26. Variation in basic wing pattern of Tipula freterns vith white in oell $R \mathrm{~L}+5$.

Pigure 27. Variation in basic ving pattern of Thoula fraterns vith white in coll $y$

Mgure 28. Variation in basic wing pattern of Hpula fraterne with white in cell $\mathrm{N}_{2}$.

Figure 29. Variation in basic wing pattern of Tipule fraterna with white in cells $R_{3}$ and $R 4+5$. 


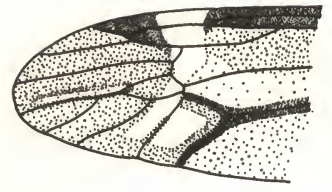

26

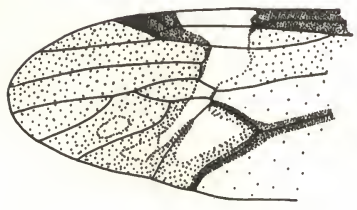

28

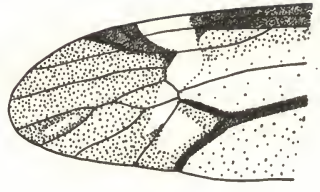

27

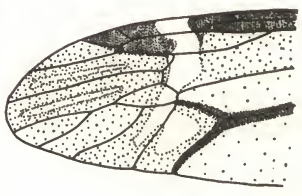

29 
confraterma shows a simdiar development. In this species the basic pattern to be found at the tip of the wing (the cord and the region beyond the cord) is a patch of white in cell R $4+5$ as well as in cello M3 and M4 (Figure 32). This pattern varies silghtly as does the basic pattern of I. fraterna, but the petch of white in the cell $\mathrm{R} 4+5$ covers nearly all, except the proxinal half and an extrene distal portion, of the cell. This patch is also characteristically rectangular. Variations which oecur much leas frequently Inciude lighter brown to nearly white areas in celle MI and H2 (FIgures 33 and 34). Although no data are avaflable to substantiate the concluslon, the latter color variations may be due to the same factors suggested as affecting $\underline{T}$. Praterna, 1.e., ecological conditions and genetic inheritance.

In one specimen of I. confraterna collected near Mountain Lake, Virginia, by J. S. Rogers, the cell N2 has an extra vein extending from the proxdmal tip of vein 13 into cell 12 (FIgure 35).

Differences and similarities of the ninth tergo-lobe are equally as subtle as those of the wings, but a measurement is here constdered which, in ay opinion, will serve as one of the valld characters for the separation of the two gpecies. This meesurement is the same as that described for I. fraterna in which Lines are projected along the tergo-lobe until they moet and the angle messured. Although not many specimens of I. confraterns are avallable, I an convinced that this angle, coupled with the basic wing pattern, can be used for the separation of I. fraterna and I. confraterna. As shown in Figure 36, the angles of T. eraterna range from 15 degrees to 52 degrees, w1th a moan of 35 degrees in a total of 228 
Plate 13

Figure 30. Variation in basic wing pattern of Tipule fraterna Pound in Stone County, Miseissippi, and the Littio Bscambis River in Eecembia County, Alabans.

Higure 31. Variation in wing venation of Ifjula fraterna show ing spur at angle of Ps. 


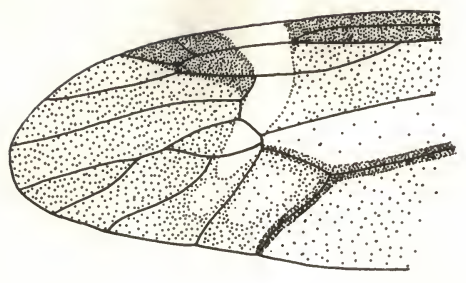

\section{0}

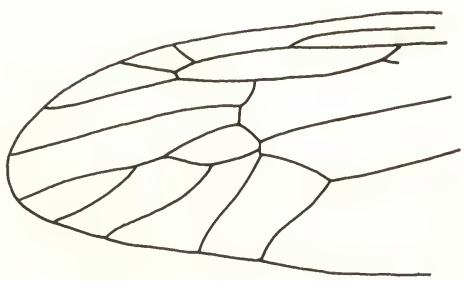

31 


\section{Plate I4}

F1gure 32. Basic wing pattern of 포미요 confratema.

Figure 33. Variation ì basic wing pattern of Tipula confraterna wh thite in cell $\mathrm{H}_{1}$.

Figure 34. Variation in basic ving pattern of Tipula confraterna with white in cell $\mathrm{N}_{2}$.

Figure 35. Variation in ving venstion of Tipyla confraterna with extre vein in cell $\mathrm{M}_{2}$. 


\section{Plate 14}

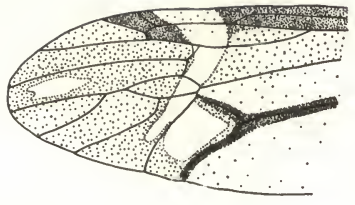

32

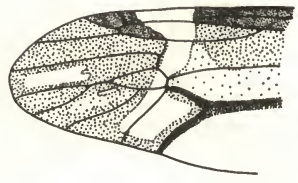

34

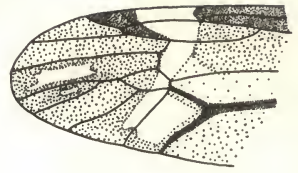

33

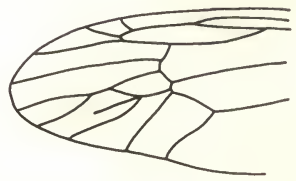

35 
81.

Plate 15

Migure 36. Comparison of tergo-lobe angles on (A) Mivuia fraterna and (B) TIpula coniratexna. Angle of tergo-lobe indieated in degrees. 
Plate 15
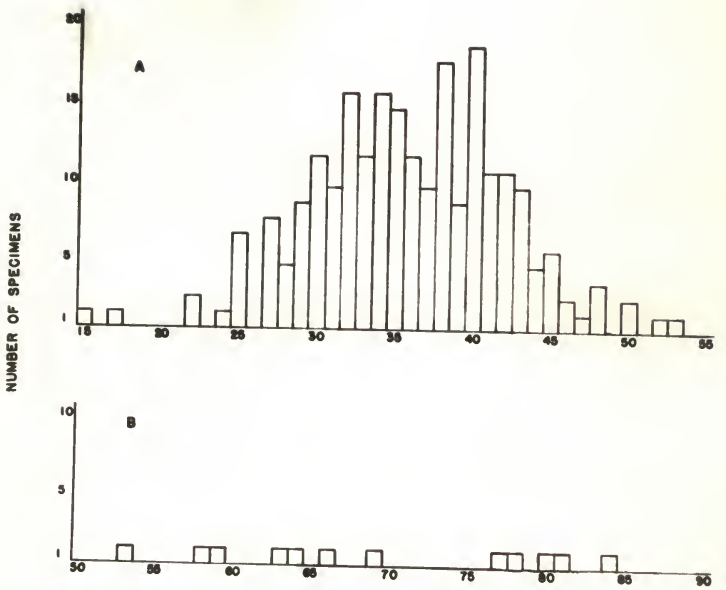

ANGLE OF TERGOLOBE

36 
Plate 16

Figure 37. Basic ving pattern of Tipuls strepens.

Figure 38. Varlation in basic wing pattern of mpula strepens. 


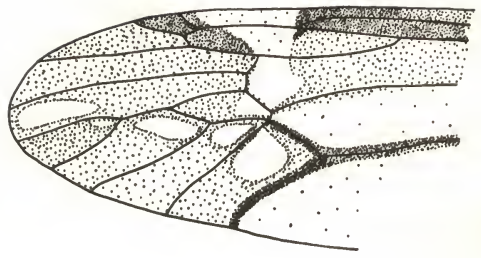

37

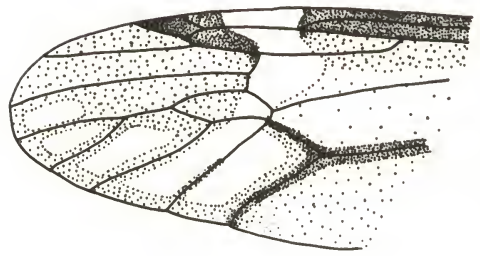

38 
specimens measured; while the angle of the tergo-lobe of I. confraterna ranges fram fifty-three degrees to eighty-four degrees, with a mean of sixty-nine degrees in a total of twelve specinens measured. Other spec1mens considered to be confraterns which were examined but not dissected and measured are obvilously with in the range of confraterna.

The variation of the outer dististyle of confraterns closely paraz lols that of $\mathrm{T}$. Praterns, with some specimens having a pronounced tuft of setae along the mical caudal edge of the outer dististyle and others without this feature.

Sise and coloration are virtually Identical with that of $\underline{T}$. fraterna. Again no definite clines can be determined from the avallable specimens.

Intergradation of $\mathrm{T}$. Preterns and $\mathrm{T}$. strepens

Rogers' speculation ( soe page do that I. fraterma and I. strepens intergrade, egpecially in the area of hountain Lajoe, Virginia, can be understood more clearly in the light of the range of variations that I have discovered in T. fraterna. The basic wing pattem of I. strepens Is derined as almas having the whitish fascia in cells $\mathrm{K5}, \mathrm{MI}, \mathrm{K}, \mathrm{M}$, and M4. The variation of this condition is the size of the ares within each cell (F1gure, 37and 38). This area may be quite narrow in some specimens, quite brosd in others. The basic pattern, hovever, rensins the same. The Nountain Iake series collected by Hogers agrees idth the basic pattern and all specinens fall within the normel range of variation of $\mathrm{I}$. strepens. The tergo-lobe of strepens is thick at the base, extending caudad for a short distance, then abruptly curving imward at both sides 
to produce a small lobe reserabling that of $\mathrm{I}$. confraterna. In undissected specimens, the thick base of the tergo-lobe is only vaguely seen and might be mistaken for the maln portion of the ninth tergite.

The outer dististyles of I. strepens are similar to those of I. Iraterns and confratema, but with much more pronounced apieal cephalo and apical caudal lobes at the distal tips than ef ther of these spocies. The setae are evenly distributed in all specimens examined. The inner dististyle elso shows similaritios but the ventral lobe 1s much smalier than that of ed ther I. fraterna or T. confratema. In addition, the articulation of the inner dististyle to the tergite faces wuch more forwerd than In I. Iraterna or I. confraterna (compare Figures 39 and 40 ).

The lateral arms of the aedeagus give Inality to the above evidence when conpered to those of I. Praterna and I. confraterna. The lateral arzs of the two latter species are blade-like without any abrupt widening at the tips of the blades. Those specimens of the Mountain Lake ares show the atreoens condition of an abrupt brosdening of the distal portion of the blade as is shown in Figure 4l. I can Find no evidence that would lead me to believe that intergradation has occurred between T. Iraterna ox T. confratarna and T. strepens.

It is interesting that the color patteins of the wiugs of I. fraterna and $\mathrm{T}$. confraterns vary to the extent that some overlep may be seen between theirs and those of T. atrepens. Arong with this basic color pattern the shape of the tergo-lobe can be used with ease to separate the species. The similarities only serve to emphasize the close relationship of the three species. 
Plate 17

black). Hgure 39. Inner dististyle of Iipula strepens (articulation bleck). Mgure 40. Innex dististyle of Mipula fraterna (articulation Figure 42. Sketch of aedeagus and Isteral arms of Tipula strapens. 


\section{Plate 17}
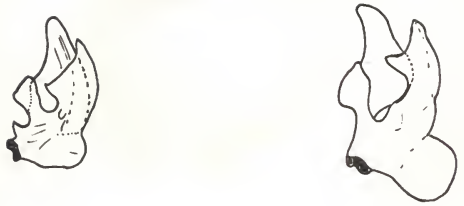

39

40

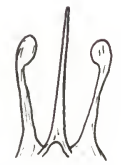

41 


\section{Description of Neotype of T. fraterna}

The type material from which Tipule fraterns was described has been reported as lost (Alexander, 1915). Dr. Alexander (personal carmunication) Inforved me that the late Dr. Nathan Banks had since examined the type material of certain species described by loew (1864) In an atteript to find some of those types which were evidently lost. I wrote to Dr. P. J. Darlington at the Museum of Comparative Zoology, where this material is located, asking if Dr. Banks had been succesaful in locating the insects, particularly Tipula fraterns. This letter was answered by Dr. W. O. Brown, in the absence of Dr. Darlington, who informed me that he was "unable to find any material among the tipulids that is in any way marked as related to Fipule fraterna, or that one might reasonably take as type material of that apec1es." Since both Dr. Alexander and Dr. Banke had examined this material and could find no type which referred to I. Iraterna, I mast assume that the type of ripula fraterns is indeed lost.

As a result of the lack of a type and of the study on variability of adult structures, I belleve that a neotype for the species Fipula sraterns should now be erected. In piciding the specimen to serve as the neotype, I used my conception of the speciso and also followed as closely as possible that, which in opinion, Loew, Alewander, and Rogers had in mind.

In the following description and that of the new species, I. confraterns, I will follow closely that form which has been set by Dr. C. P. Alecander, whose descriptions of T. Plomdensis or I. maculipleura, 
would serve, for the nost part, as a description of $\mathrm{T}$. freternas however, some modiflcations are deened necessary.

Due to the lack of T. fraterna adults from the type locallty at Washington, D. C., a æpecimen was chosen from among a lot teken in Macon County, North Carolina. This region is the closest locality to Washington from which specinens are avallable.

Typuls Praterns Loew (neotype)

Wing length ${ }^{2} 26.50 \mathrm{~mm}$. Body length: $15.80 \mathrm{~mm}$,

Head: Frontal prolongation of head obscure yellow, nasus long, slender, dorsal surface sparsely pruinoses pelpi brown. Anternae, if bent backward, extending slightly beyond base of abdomeng besal segnent dark yellowishmbrown, second segnent concolorous, both segnents sparsely pruinose; the f1rst Plageller segment jollow with base vagualy darker. Remainder of rlagellax segments bicolorous, nearly black at base with distal portion of each segment yellow. Bicolorous condition becoming obscure at distal flagellar segments gradualy becoming nore Infuscated and darker. Head dark gray prufnose, vertex lighter; head with dark median vitta extending from vartex to occiput.

Thorax: Pronotum brown, mesonotal preescutum browndsh-gray with three brown stripes, all Indistinctly bordered with daricer brown the median stripe with a dark brovn median vitte which becomes obscure before the suture; scutum browish-gray pruinoses scutellum paler yellowlshbrown Eræy prufnose. Ploura light gray pruinose, slightly darker at

Wwing length is meesured from the inner margin of the tegula to the tip of the wing. 
propleura, sternoplourite, anterior anepisternum, and eplsternum. Helteres pele brown with knobs darker. Legs with coxae yellow, faintly black at posterlor base; fenora brownish-yellow, darkening slightly at distel tips, tiblae darker brovish-yallow; remalnder of leg segments beconing darker with tervinal sognents of tarsi brownish-black. The entire apex of the wing dark brown; the inner end of the stigma yellow, the distal end dark brom; oell II peler; a narrow but conspicvous whitish band transversing wing at or a little before the cord, extending from the stignal area into cells $\mathrm{M} 3$ and $\mathrm{ML}$, and the inner end of cell lat M2. Veins dark brown except in aree of the whitish band. Venation, basal section of $\mathrm{R} 2$ about $1 / 2 \mathrm{r}$ cell lst $\mathrm{N} 2$ relatively long and narrows petiole of cell in about one-thind the cell $\mathrm{VI}$.

Abdomen: Abdominal tergites pale yellowish brown, with broad dark brown sublateral stripes, laterel margins paler, the former vague at the second abdominal segment, darker in Plrst and other segments. Sternites pale yellotr-brovn anterlorly, becoming dark brovn at terminal segmente. Hypopygium with caudal margin of ninth tergite bearing a consplevous, strongly depressed and slightly triangular, median 10be, the tip of the lobe bluntly rounded, the sides narrowing to an angle of thirty-nine degrees (Figure 42). The outer dististyle compressed, with vague apicel-cephalo and apical-caudal lobes; setae slightly tufted in appearance at apical-caudel odge. Winth sternite with a deep, V-shaped notch, the margins fringed with consplcuous elongate setae.

Neotype: Nalez Nacon County, North Carolina, at Highlends, alt1tude 3,800 seet. June 21,1934, J. S. Rogers, No. 50 (sLide no. 684, Hynes). 
Topotypes: Five males; Macon County, North Carolina at Highlands, June 11, 1934, J.S.R., no. 50 (S1ide no. 6660, J.S.R.). Six maleas Kacon County, North Carolina at Highlands, 3,800 feet. June 12, 1934, J. S. Bogers, no. 58 (SIIdes nos. 6658, 6659, J.S.R.). The neotype w11l be deposited at the University of M1ahigan Museum of 200Logs, Ann Axbor, M1ch1gan. Topotypes are deposited at the Iniversity of Mchigan Musewn of Zoology, and in the Univeralty of Florida Collectlons, Gainesville, Morida.

Description of Tipula confraterna sp. n.

Wing length: $16.50 \mathrm{~mm}$. Body length: $16.50 \mathrm{m.}$

Head: Frontal prolongation yellow-brown with doreal area sparsely prulnose, nasus long, slender, and some colors palpi brown. Antennas of moderate length, in male if bent backward would castend to base of abdomen. Basal segment yellow-brown, sparsely prufnoses second segment concolorous; first Plagellar segnent yellow second flagellar aegnent with mere suggestion of black at base, remalnder of segment gellow; remaining segnents bicolorous, with more distal segnents beccuing more unfformiy infusoated. Heed gray, pruinose, anterior vertex IIghter, dark median vitta from anterlor vertex to occiput.

Thorax: Pronotum brova. Mesonotal praescutum brounish-gray with three brom to gray pruinose stripes, all distinethy bordered with darker brown, the median gtripe vith a dark brown medial line beconing obsolete before suture; scutum brownish-grey pruinose; soutellum grey pruinose. Postnotal medioterglte light gray, pruinose. Pleura gray pruinose, eplaternum darker. Halteres dark brown, knobs darker. Logs with corra pale gray prulnose, trochanters yellow, the tipa narrowly and slightly derkened; tiblae brownish-yellow; targi brownish-yellow darkening gradualy 
to brovalsh-black at terainal segments. The apex of the ufng dark brovm axcept for cell $\mathrm{R} 4+5$ whlch has an elongate pale white patch located distally in the cell, the remainder of the wing dark brown except for cell $\mathrm{Cu}$, which is largely whitish, basal portion of $\mathrm{I}$ and first anal cell also whitish. Proxdmal portion of stigmal ares yellow, distal ares dark brown; consplcuous, whitish, obliterative band crosses the wing extending from the yellow stigna to the base of M3 and including the basel portion of cell lst 122 and a major portion of cell $\mathrm{MH}_{4}$.

Abdomen: Tergites pale yellowish-brown with broad, dark, sublateral stripes; lateral margins broadly paler and pruinose; posterlor tergites with dark brown spreading across entire tergite; sternites pale yellow anterioriy, becoming darik brown at posterior end, Male hypopygium with the caudal margin of ninth tergite bearing a conspleuous, broadly triangular-sheped, strongly depressed, median $10 \mathrm{bes}$ tip truncste, the sides of the lobe narrowing to an angle of seventymeven degrees (Figure 43). Outer dististyles with slight apical-cophalo and apical-candal lobes at distal tips; slightly tufted setae occurring on aplcal-caudal Lobe.

Holotype: 1 male; H1clenan County, Tennessee, at Centervilie. June 15, 1956, Hynes $\#$ 6-1556-1. S1ide of genitalia (Hynes \# 683).

Paratypes: 2 males; Tusceloosa County, Alabana, at Gin Creek. June 16,1954 ; Hynes || 6-1654-1. S1ide of genitalia (Hynes || 349). Tour males (one teneral): Hardin County, Tennessee, at Second Creok. June 9, 2956. Hynes \# 6-956-2.

Holotype wlll be deposited at the University of Michigan Museum of Zoology, Ann Arbor, Michigan. Paratypes will be deposited at the University of Florida Insect Collection, Gainesville, Forida. 
94

Plate 18

Figure 42. Neotype of $\mathrm{T}$. Iraterns. Left: tergo-lobe. Right: outer dististyle.

Flgure 43. Holotype of $\mathrm{I}$. confraterng. Left: tergo-lobe. Right: outer dististyle. 
Plate 18
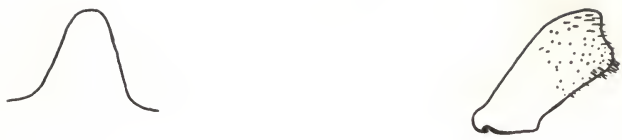

42
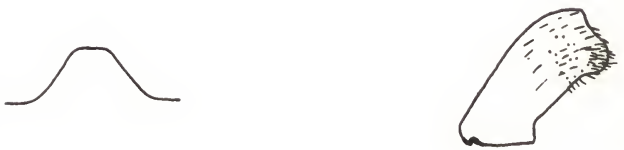

43 


\section{RURPODUCTIVE BEHAVIOR}

Premcopulatory and copulatory behavior of T. fraterna and I. confrateran; although not basically different from that described by Pogers (1933) for the general mating behevior of tipulids, or Byers (1952) for the genus Dolichopeze, did show scue variations.

No difference in bohavior could be noted between the species, I. fraterne and I. confraterna. At no time was swarning of meles or females noted, and I feel certaln that swarming, in the sense that is conmonir thought of In IIpuridae, does not take place in this complex. Rogers also mentioned that males would rematn near a pupa of the fevale which, upon emergence, would be seized for copulation. I have not seen this type of blhavior. Rogers does report having seen both swarming and early selsure of females in I. celoptere. Indeed, the results of mating-cage experiments lead me to belleve that malas of I. fraterna will seldom copulate with a teneral fenelo.

When the two species are mixed, the behavior, regandless of the sex, varles from a neutral to avoidance reaction. In only one case have I seen an attempt by a male of I. Iraterns to approseh the female of I. confraterns, and in this case the behavior on the part of the female was not active rejection, but pasalve avoidance as will be described later. In no case did I observe a male of I. confreterna approach the fenale of T. eraterna.

A distinction has been made between prowcopulatory and copulatory 
behavior not only for elarity in the following discussion, but because there seem to be ainor activities which take place during each phase. Premcopulatory activity begins with the ayproach of the male to the fomele. If the female is receptive, she remains passive, occasionally fluttering her wings in order to maintain belance. The male approaches from behind and drapes his legs over the female. Usually the prothoracte legs alone, and rerely the mesothoracic logs, are placed over the anterlor edge of the wings of the fensie to prevent the fenale from flying. If the fomale does vibrate bar wings, the male becomes very active, atteupting to maintain a hold on her wings to keep her imnobile. Simultaneously the male curves the abdomen under that of the female and clasps it with the outer dististyles of his genltalie. The dististylos now work back along the ferale's abdomen alternately grasping and releasing it untis. his genstalla reach the posterior end of the female, PInally coming to rest at the angle of the cerci and the hypovalves. The posterior end of the male's abdomen is now curved in such a manner as to place the hypovalves in an area ventral to the tergo-lobe. At the same time, the Inner dististyles fit into the aypovalves so that the inner lobe "12 fits into the medial inner groove, and the amaller lobe ff $\mathrm{flts}$ along the outer edge, while lobe $/ 3$ rits the opposite edge and is nearly in line with lobe H2. How the cercl and the hypovalves are forced apart by the genitella of the male has not been determined. Byers reported that the gonopophysis of Dollchopeza served this function. The further separation of the sercl, however, is done by the ventral edges of the ninth sternite and the ventral lobes of the inner dististyle, 1.e., lobe M. Meanwhile, the tips of the lobe $/ 1$ of the inner dististyle are now located in a cavity 
just ventral and anterior to the hypovalves. The tergo-lobe is then Iowered into a depression just dorsal and anterior to the hypovalves, in order to maintein a rise-14ke grip on the area. The grasping of the hypovalves appears to be the function of the tergo-lobe. The ventrel lobe All, of the inner dististyle comes to rest at the medial margin of the cercl, while the dorsal lobes, $\# 2$ and $/ 3$, retain a grip on each of the blades of the hypovalve (Figure 4h). The legs of the male now release their hold on the female and he swings downwerd with the fenale supporting him. This results in the ventral surface of the female and the dorsal surface of the male being oriented in the same.direction with wings held outwaxd in the nomal position. The penis is now Inserted Into the genstel pore of the fomele, and pre-eopulatory behavior is considered to be at an and, and copulation has begun.

After watching many pairs of crane-files in copulation, I feel certain that there is a type of behavior present, not previously recorded, In which the males during copulation jerle one or two legs in a rhythmic motion occurring at the rate of about one movement per second. Later during copulation, this jeriding stops. After the terridnation of this unique motion, the nale may atterpt to reloase itself from the copulatory position, or may continue to hang from the fenale ut th no visible motion from of ther. If the male and fente are disturbed during copulation, they will separate, and the jerking motion of the mule continues for some time oven though there is no contact with the female. This activits has been observed both in nature and in the labolatory. It has also been observed in other species of the tricolor group in addition to To fraterna and I. confraterns. 
Plate 19

Figure W4. Position of genital structures of male and fenale Tipula fraterne during copulation. 
Plate 19

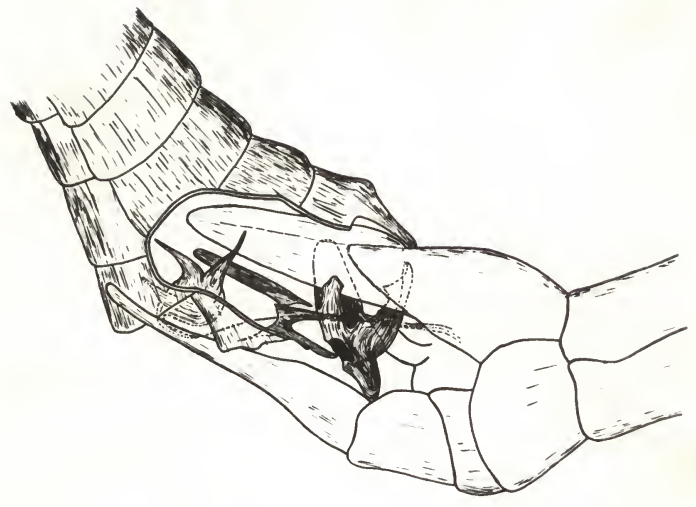

44 
There are sane additional observations and facets of the behavior of I. Iraterna and I. confraterna which I feel deserve more attention than I was able to sive them during the course of this Investigation. Mating and copulation of T. fraterna and T. confraterns begins at dusis or twillght and in the early moming. The langth of time reguired for copulation in nature is not lnown; but in the laboratory some palrs contInued for as long as three houra. Copulation does not take place until the light diminishos. Pairs that are found in copulation in carly moming will separate before the noming is far advanced. Behavior of oviposition also appears to stop about this tine: Both males and females then asaune the resting position unt1l the light again recedes: Resting may be intermpted intermittently by the insects' flying from one reating place to another.

Putting several males and females of one or both species of the fratema complex into a cage usualiy resulted in a haphasard series of MIghts around the cage. No attenpt to seois the male or the female on the part of the opposite sex covld be seen. Only when the males and fomales approached each other closely was there any positive reaction or attengt to mete. The close proximity of the two sexes in nature may be due to the habitat requirements (Rogers, 1933; Byars, 1952). However, in experiments using T. fures, a behavior is seen which alght provide an enswer to ths problem of how anales and feneles locate each other. A male of T. furca was put into a cage and allomed to settle.' When a female was introduced, the noise produced by her wings stimulated the male to leave his perch irmediately and $\mathrm{fly}$ directly to the fenile engaging her in copulation. This might suggest that wing vibration 18 one method used by 
male crane-ples to find fensles.

Uaually when a fenale of I. confraterna was introduced into the cage along with a male of T. Iraterna no movement was seen on the part of either Individual; nor did the reverse situation in which a I. Pratema fenale and I. confraterna nale were brought together result in any noticeable behavtoral differences. In only one case did a Is fraterna male attenpt to begin mating with a female of $\mathrm{I}$. confraterns. The fenale, however, merely sidled away. Normal rejection of the mele by the female In efther species consists of a violent kdeling and vibration of the vings. If this does not produce the dosired affect, the famale flies violently to the botton of the cage, at the same time kicking her legs, so that both individuals, upon hitting the botton, are imediately separeted. This act may be repeated several times before the male ceases the attempts to mate.

In another obeervation of a $\mathrm{T}$. fraterna fenale and the male of another species of tricolor group, pipula sp. (close to tricolor), the male was able to assume a mating position with the remale but wes unable to hold her genitalla, apparently for mechanical reasons. These two types of reaction indicate that behavior may serve to keep soree species epart, while in others, the mechanical connections of the genfitalia a are not suitable for the two to carry on normal copulation.

Several times the following situation was observed in the eage. One pair of T. fraterma Individuals was in the state of active copulation and would be approached by another male of exatema. The unatteched male would then attenpt to copulate with the fenale who was already engaged in in this activity. Sorsetimes this resulted in the copulating male's being 
pushed awry fron the female; other tines the male would successfully malntain hls hold on the fenale. Such attacks nay indicate aggressive behavior on the part of meles. It would be interesting to set up a hierarchy study with the femele as the goal to deterrulne whether such a phenomenon does exist in Tipultiae. No attengt to collect such data was mede, as this 11 es beyond the present scope of this problem.

Various combinations of matings between the species I. fraterna and I. confraterna were attenpted with observations from eight separate groups of Individualo taken from as many locations. In any one group, nales and females of $T_{0}$ fraterna and then of $\underline{I_{0}}$ confreterne were put into the cage to determine if they would mate with each, other. If they did, they were then returned to small containers until used in later exper1ments. This served as a control to test whether an Individual was mature and ready to mate. Then combinations of $\mathrm{T}_{0}$ frakerna males and $\mathrm{T}_{0}$ confraterna fenales were tried, but no attempts to mate resulted. The roverse corabination was 2 lso tried with only the one case, recorded above, In which the I. eraterna male approsched the I. confraterne female. At no time during experiments vith any combination in single pairs or in aroups of one sex of one apecies with a single Individual of the opposite sex of the other specles did I. Ixeterna or I. confraterne wate with oach other, although they inated freely among themselves prior to this time. After such combinations had been observed, as a further check, the meles and females of both apectes were put into the cage at the same time. In every case where mating was observed, the male of fraterna went to the fraterna females, and males of coneraterna went to the females of $\mathrm{T}$. confraterne. The selectivity of males and fomales of these two groups 
frumishes additional evidence of their speciflcity.

Oviposition usually follows soon after mating. The fenale, during oviposition, can be seen to bounce contimuously. During the bouncing, the boty is oriented with its ventral side parallel with and toward the bank, 1ts head up and forwand towerd the bank, and the abdomen curved down and forward. The female exies to within three to six inches of the side of the bank and about two to four inches above the vater level. She then moves towrard the bank, touching it with her tars1, and at the same tire swings her abdomen forward so that the hypovalves and cerci enter the so11 horizontally. She then Plies away from the bank alded by a springing motion of her legs. This sction is repeated about elghty times per ulnute. The greatest length of time that this ectivity was observed to continue was twenty-e1ve ainutes. I do not know if, or how many tines, this sequence of behavior may be repeated. Occasionally the valves become stuck in the soil. When this hagpens, the female increases the speed of her wing vibrations and pushes vigorously egefinst the soli with her legs. The female has never been observed pushing Its abdomen deoply into the soll or penetrating more than the length of the valves themselves.

Sometimee the female vill bounce in a vertical fashion over the surface of the water. Thls may occur just prlor to or inmediately after oviposition. I could not deternine whether or not eggs were being lald at this tine.

After campleting oviposition, the female Plies to the low branches overhanging the strean and assumes the resting position.

To deternine the mumber of eggs ejected at one time, I allowed the female to continue the bouncing dance for as long as possible, then 
that portion of the bank was cut away for observation under a microscope. Examination of this material revealed that one, sometimes two, and rarely three, eggs would be found at any one point in the site. Several of these extirpated ova were kept in the laboratory unt1l they hatched ao that Identifiostion could be confinned. Observation of the hypopygium of the decapitated females in the laboratory revealed that the xhythmieal action of the ovipositor corresponded to the rhyth or bouncing action of the oviposition flight. The eggs were usually ejected one at a time, but occasionally one adhered to the hypovalves and the ojection of the following egg would then force both eggs out onto the damp botton of the cage. Such a situation would explain finding egge in two's and three's at one point together in the habitat.

The eggs are ejected with considerable force. In containers, four Inches square, with the decapitated specimen at one side, the eggs are scusetines ejected with such force that they are throvm to the opposite wall. I was never able to determine whether the depression or ralsing of the cerel vas responsible for the force with which the eggs wore eliminated.

When the eggs are ejected into water in the bottom of the container, the hold-fast soon becones uncolied and attaches to any debris or to the hold-fusts of other eggs. The advantage of this structure is es pecially evident when one considere that the ares in whlch the eggs are latd is that in which the greatest amount of erosion takes place. The egg will be held in the area by the filment to rooth withis the soll. Byers (1952) also reports this structure to be present on the eges of Dolfchopera and 
It is present on the ecgs of all species of the tricolor group which I have examined to date. Hermingsen (1952) has associated the hold-fast with ove deposited in water. The presence of the structure on fraterne eggs leads to the conclusion that this group is basically aquatic except In the adult stage, and even though oggs are now lald above the water Ine this characteristic has been retained. 


\section{IMMATURE STAGES}

The immature stages of T. fraterne have been collected and associated with the adult for confixmation of Identification. Of the Innature stages of $\mathrm{I}$. confraterns, only the pupa can be differentiated from those of $\mathrm{T}$. fraterna. The first and fourth larval stages are described; as the second and third inatars follow closely that of the fourth instar, except for aise differences, these stages are not treated separately.

\section{Igg}

The egg possesses a long filamentous hold-fast at the end opposite the micropyle. It is yellow, alongate, slightly concave at the ventral surface, and bluntly rounded at the ends; the micropyle is prominent. Length: $0.814-0.93$ m. : widh: $0.28-0.31$ me. Figure 45 .

\section{Birst instar larve}

The first instar larva, upon hatching, is nearly translucent and white, with many short and a few long setae covering the body. A short time after hatching the color changes to that characteristic of the later 1nstare. The body is terete and stout. The spiracular disk appears as shown in Flgure 46. The anal lobes are nilk white, and, have aix lobes present with the posterior ventral lobes appearing only slightly (F1gure 47). Sowutimes the posterlor ventral lobes cannot be seen at all. The length of the larva varies from $1.59 \mathrm{~mm}$. to $4.52 \mathrm{~km}$, depending on age. The head capsule ranges from .26 m. to .39 m. The head capale (Mgure L8) does 
Figure 45. Egg of $\mathrm{T}$. Praterna.

Figure 46. T. fraterna, spiracular dis $\mathrm{j}_{\mathrm{k}}$ of first instar larva. Figure 47. To fraterna, anal lobes of FIrst instar larva. F1gure 48. T. Eraterns, head capsule of f1rat instar larva. (A) ventral view, (B) dorsal view. 
Plate 20

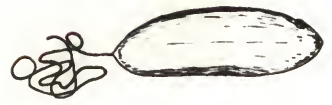

45

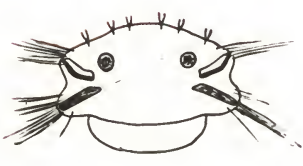

46

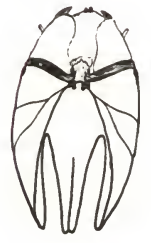

A

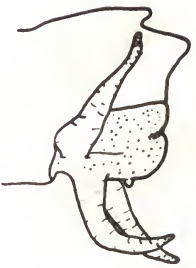

47

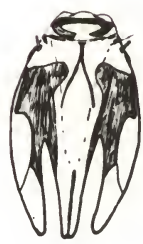

48 
not darken or harden complotely. The mandibles, the areas surrounding the ocular plate, the labium, the labrum, and the areas fron the ocular plate to the clefts of the head capsule are modorately dark. The edges of the dorsal portion of lateral crantal fragment and the lateral edge of the dorsal cranial fragnent plus the coronal suture are dark, as well as the strip extending from the besel mandibular articulation to the mexdllary plate. The maxdlary plate (Figure i49) has seven teeth. The aplcal tooth is the longer, but, unlive those in the fourth instar, the teoth appear much sharper. The prenentum is also toothed, but appoars to have two less than that of the lnter instars, and the renainder also wuch sharper than those of the later 1nstars. The labrum of the first instar larva is separated from the clypeal region by a suture which is located directiy in front of the antennal plate. The elypeal-labral rogion is shown in Figure 50. The margin of the Labrum appears to be oniy feebly trilobed. The laterel areas are fringed with setee which project forvard and slightis mesed. Mso lateral to the central area, on either side, occur two thick setse which originate on the dorsal portion of the chitinized plate. These setae also project forward and alightly mead, and as for as the fringe of setal haire described above. The central lobe possesses many very tiny setae. Mesad to the antennae and just caudad to the clypeal-labrel auture is a ralatively large papilla whtch points obliquely cephalad. Directly mesad to the papinla there is one long setal hair. On the rest of the clippeal-labral region, especially the lateral portions there are five or six areas which appear to be senaory pits. Another structure, here unnomed, on the elypeal-labral reglon, 
originates just posterlor to the elypeal-labral, suture on the mid-line of the head capsule. The structure then projects posteriorly and gives off two arms, one to either side, which then end about level to the posterlor lateral sutures of the ocular plate. I have found no evidence of the presence of this structure in the other larvel instars. No reference is made to this structure by any of the previous authors. I heve also found this structure in every first instar larva of other species of the tricolor group which I have wamined. What the orlgin of this structure 1s, or what 1 ts function was be, remains unknown. I thought at one time that It might ald in the escape from the egg, but there is no proa?.

The mandible (FIgure 51) is yet another structure which varies greatly from that of the later larval instars. The apleal portion of the mandible has three teeth wich are acute and elongate and point directly forward along the medial line. Just basal and mesad to the apical teeth, occurs another arm at the tip of which are two sharp teeth. There are other amaller lobes on the mandible, but I an not sure whether these appear as variations or are oonstant in the structure of the randible.

\section{Bourth Instar larva}

The fully mature larva (Figure 52) when alive may have ollght coloration due to the habitat from which it is collected, because of amall particles of elay which adhere to the exoskeleton. When preserved most of the particles are washed off by the alcohol and the true color is seen to be white with yellowlsh casts. The anterior segments sometimes are a pale, golden yellow, Slecked with black due to the presenee of setae of the type shown in Figure 53. The body becomes darker at the 
Plete 21

Figure 49. I. fraterna; maxdlary plate of first instar. Larva. Flgure 50. I. eraterng; clypeal-labrel reglon of flrst instax Figure 51. T. fraternas mandible of first instar Iarva. 
Plate 21
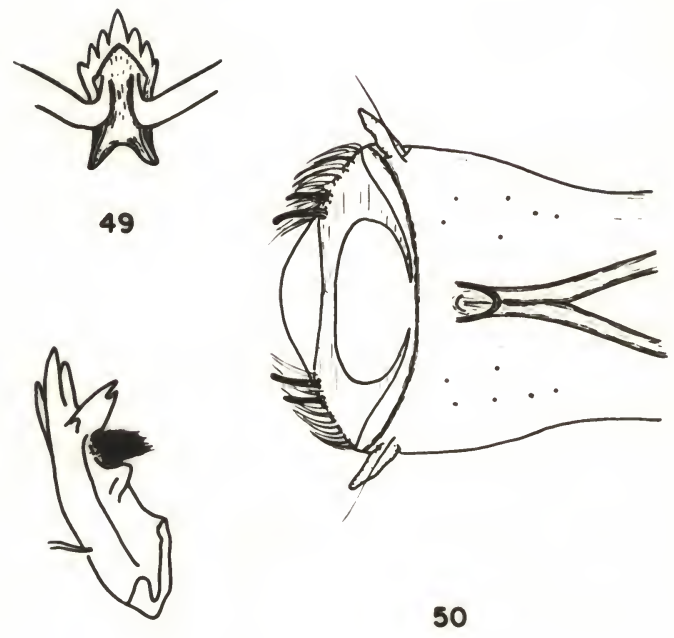

51 
114

posterior end, especially on the dorsel side. This is due to a heavier concentration of setae. The pleural region sometimes becomes noticeably darkened, giving the larve the appearance of possessing lateral stripes. This condition may occur naturally, or may occur as a result of preservetion. The posterlor and is truncate, with six consplcuous lobes of the spiracular disk present; the slx whitish anal lobes present on the tenth segment are subdivided into a pair of lateral anterlor $10 \mathrm{bes}$ and two ventral anterlor lobes which are subequal in Length, and directly posterlor to the latter are a pair of posterlor ventral lobes which are slightly maller than the other two parrs. There are no ereeping welts occurring on elther the dorsal or ventral surface of the body. The chaetotaxy of the long setal hairs and pencils of setal halrs are shown in Figure $54 \mathrm{~A}_{3}$ B, $C$, and D:

The boundaries between the tergal and pleural and sternal and ploural areas are indistinct except under high nagnifleatlon. Under such conditions it is possible to see abrupt differences in the arrangement of the setae in these regions. The pleura have smaller and differant arrangements of setse than the sternal or tergal areas. The latter are very simfiar. There are tufts of small setae surrounding long, single setae which occus at the posterio-lateral edges of the tergal and sternal areas of abdoninal segments two through seven. Tho mabers of setae increase on the tergal and sternal areas of the abdominal segments six and seven. The eighth abdominal tergal ares has a noticeably increased number of setae, in which the long aingle setae, so prominent in the other segnents, are no longer present or have been obscured by the presence of 


\section{Plate 22}

Figure 52. Tipula Praterna, lateral view of fourth instar larva.

Figure 53. Setal type which gives partial black coloration to anterlor body segnents of Tlpula Iraterna larva.

Figure 54. Chaetotexy of segments of Tipola fraterna fourth Instar larva. Tergel, pleural, and sternal areas shown from left to right. (A) First thoraclo segment. (B) Second and third thoracie regments. (C) First abdominal segment. (D) Second through seventh abdominal segments. 


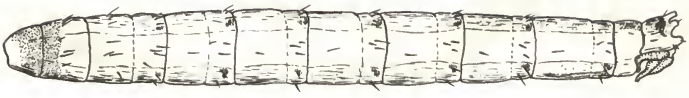

52

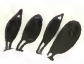

B

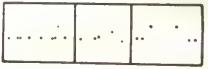

53

c

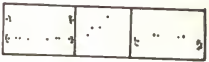

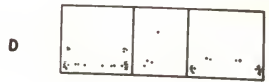

54 
the others. The eighth stemel area has four evenly spaced, long, singlo setae placed slightly posterior to the middle of the segment; tufts of moderately long setae are absent. The ninth tergal aree has setae appearing in dense quantity just previous to the tergal lobes of the spiracular disk. This also gives a very dark appearance to the tergal area.

The spiraeular disk (Figure 55) has six lobes, the lateral and ventral pair being subequal. The dorsal pair of lobes are small; all lobes bear a fringe of short setue on their margins, At the tips of the ventral pair of lobes occurs a single, long, sensory hatr, the length of which is alightily less than half that of the lobe. The ventral lobes are marked with a chitinous plate with a medial stripe, extending from the base of the sensory hair to about mid-length of the plate, At the basal margin of the plate are three heavily ohitinized spots, which become smeller laterally. The lnteral lobes have a triangular plate which abuts bagally almost to the gpiracle. The ventral margin of this plate is more deeply colored foming a stripe. The dorsal lobes have triangular plates, the ventral nedial margin lying close to the spiracle. The medial and lateral margins of the plate are more heavily chitinized than the remainder of the plate giving the appearance of two stripes; the medial broader than the lateral, on each plate.

The tenth segment of the abdomen is subterminal, surrounding the anal opening and possessing six anal lobes described above. The entire segment is sparsely armed with setee, and much whiter thon the rest of the body. A long setal haly is located in the area which is probably the pleural region of this segment. 
The head eapsules of several tipulines have been described by several authors including Alexander (1920), Oldham (1929), Cook (1949), and Byers (1952), of these descriptions, that of Cook, treating the head capsules of varlous Diptera, among them the craner1y, Holorusia rublotnosa, is the most complete and useful in interpreting the phylogenetic significance of the dipteran head capsules. His tervinology and that of Alexander's are used in the following description.

The head capsule of the fourth instar has the following dinensions: length, $2.53-2.08 \mathrm{mn}, ;$ width, $0.7 \mathrm{~h}-0.93 \mathrm{~mm}$. The head capeule is massive and compact. The mandible (Mgare 56) with a pair of teeth at the apleel margin, which are prominent, deflected ventrally, separated slightly frow another pais of teeth along the ventral edge. The dorsal odge possesses indistinct teeth. Prosthecal tuft shown in 71 gure 57 , the body of the mandible is heavily ahdtinized.

The madila (Figure 58 ) is quadrate, with the cardo nearly ta1angular but curving cephaled just before union vith other small plates. There are two short, thick, setee present at the bend of this curve. The stipes is seen as an irregular shaped plate. The maxdllary palpus is provinent and membranous, except for a chitinous ring at the tip; mesed to the palpus occurs a brush of thick setae, and mesal to this brush on the dorsal surface of the mardlla there is a median large papilla. Another brush of setae occurs along the central lateral margin of the maxdila. The lateral margin and some other portlons of the maxdillae are covered with numerous short setae.

The antennas are two segmented and chitinized except plear the apex where the apical sensory papilla is located (Figure 59). The basal 
Plate 23

Larve.

Figure 55. Tlpoin fraterna, spiracular disk of fourth Instar

Figure 56. Tipuls fratema, mandible of fourth instar larva. Flgure 57. Tipula fraterna, prosthecal tuft of andible. Figure 58. IIpula fraterna, mardlla of fourth instar lavva. Figure 59. Tipula fraternas antenna of fourth instar larva. 


\section{Plate 23}
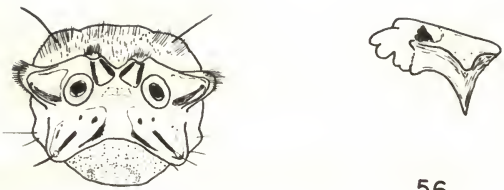

56

55

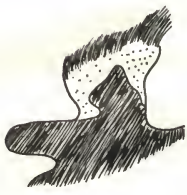

57
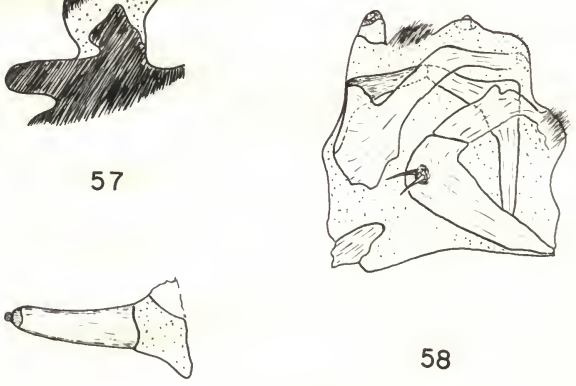

58

59 
segment is membranous, attaching to the antennal plate adjacent to the labrum. The length is four times the width, and curved slightly mesad and dorsad.

The mexiliaxy plate (Flgure 60 has seven teethy the splcal median tooth is the longest; all the teeth are rounded at the tips, not sharp. The prementum has five teeth, none sharp (Figure 61); the aplcal median tooth is the longest; the most lateral teeth are very mall. On the ventrel surfece of the labral reglon are several row of flattened heavy setae, and on elther side of the mid-line are two sanll spinous papilise. On the anterior and mesel margin of the lateral lobes there is a papilla with two long sensory halrs. Ieteral to the pap1lla and dorsally on the anterior edge there is enother sensory pepilia.

Pupa

Length, $14.3 \mathrm{~mm} ; \mathrm{width}$ at the base of the wing-pad, 2.70 mi. 5 depth at the base of the wing-pad, $2.85 \mathrm{mman}$.

Body (FHgure $62 \mathrm{~A}, \mathrm{~B}$ ) pale yellow to rust-brown; eyes, wing-pads, and leg sheaths, dark brovn; a conspicuous pelemyllow stripe along the carinate margin of the pleura from the upper edge of the wing mad at the P1rst abdominal seguent to the seventh abdominal segnent. Antennal sheaths yellow, ending at the anterior fourth of the lower edge of the wing-pad. Iabial sheaths brown, Ileshy, touching the leg sheathe of the prothorax. Sternal plates of thorax yellow-browm. Maxdllary sheaths broven, tovehing the antennal sheaths at an obllque angle, recurving cauded, ending about one-half the distance back along the main trunk, Wing-pada ending just before the apex of the second abdominal segment, 
Plate 24

\section{Iarva.}

Figure 60. Mipula Iraterns, maxillaxy plate of fourth Instar

Figure 61. Fipula fraterna, prementum of fourth Instor larva. 
Plate 24

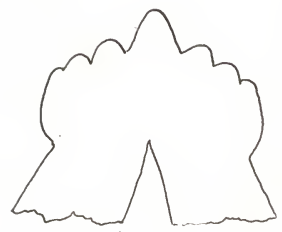

60

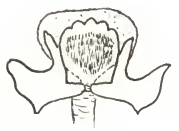

61 
dark brovm except for \& pale yellow transverse mark near the distal fourth of the wing-pad, a amall pale yellow area just anterior to this, and another Irregular, small, pele yellow mark just below and slightly caudad of the base of the wing-ped corresponding to the markings of the adurt ving. Venation usually obscure.

Leg shenthe ending midwey between the anterior edge of the fourth abdominal sogment and the false division of the segment. Ifetathoracio leg sheaths sllghtly longer than the mesothoracic leg sheaths. The cephalle erest bizobed with one or no setal present.

Mesonotal breathing horns thick at base, becoming narrower towards the thp and then suddenly expending anmulated, pointing at an obllque angle laterad, recurving dorsad at the tips; a delicate, dark brown line occurs along the entire length of the nesonotal breathing horn. Length of horns, $0.81-0.87 \mathrm{~mm}$.

The prothorex is yellow, weakly inflated, bilobed or with inlddorsal area dopressed, dark brown and sculptured.

Mesothoras at the anterfor thind is sculptured in the dorsal aree, weakly carinate at the add-dorsal line, and dark brown; also, with a more flettened appoarance. The rest of the mesothorex is rounded, appearing buraped. Extending from the carinate region to the posterlor third of the mesothorax is a modial stripe which is weakly sculptured; on edther side of this is another stripe also weakly sculptured, beginning Just caudad of the mesonotel breathing horns, nearly corrverging at the nost dorsal point of the mesothorex into a flat, oval tubercle. Cne 2ateral, blunt tubercle occurs mesad and about midway between the median ilne of the mesothorax and the base of each wing -pad. 
The metathorax is amall; with an inconspicuous ridge with three setwe on each laterel anterior margin of tergal plate. The anterior margin of the tergal plate concave; the posterior maxgin with a mall V-ahaped projection into the anterior edge of the first abdominal segnent.

The f1rst abdominal segment dull yellowmbrown with darker arees forming obseure stripes on elther side of the mid-line. A row of four tubercles oecurs on aither side of the mid-line and about one-thind the distance sephalad of the posterior margin. Darik brown pits are on elther side of the anterfor division of the tergal plate. The entire tergel plate rimned with dark brovm. Abdominal segnents two through seven are subdivided, the posterior portion slightly less in length than the anterior; posterior section of the segnent poseessing several spined tubereles; three transverse dark brown maridings on either slde of the anterior section.

The pleura of the second segrent has two spines on Its carinate edge, the anterlor much smaller than the posterlor. The pleura of the third through seventh segnents with anterior spine slightly larger, oecurring caudad of anterior margin of segnent; the tip of the spine with one setal halr; posterlor spine just cephalad of posterior edge of segment, tip with one heavy setal hadr, and also one dellcate setal hair just posterior to 1 t.

The elghth abdominal segment with tergal plate having no wpines or tubercles; pleura having one spinous tubercle below and slightly cephalad of base of anterior tergal arru of ninth segnent; sternste having four tubercles, two on each side, the mesal poir larger, all pointing slightir caudad. 
The male ceuda with anterior pair of tergal arms smaller then others, blunt, pointing directly dorsad. Iateral peir diverging alightly laterad, spinous tips curving mesad. Anterior tergal lobes with beses pointing caudad, curving unt1l spined t1ps pointing dorsad and sl1ghtly mesad. Spinous tubereles of sheath molosing inner dististyle curving dorsed and slightly mesad. Sheath for outer dististyle truneate or olightly lobed, pointing cauded and alightly mosad, Indicative of the shape of the adult atructure and following closely the varlation found in the adult. Fenale cauda with tergal arms much as in the males caudal valves not curved, pointing directiy caudad.

\section{Pupa of $\mathrm{T}_{\text {. confraterns }}$}

The only difference observed between the pupel stages of $\mathrm{T}$. fraterna and $\mathrm{T}_{\mathrm{f}}$ confraterna $2 \mathrm{~s}$ in the wing-pad of the latter specles. In addition to the transverse whitish area described in the pupa of fraterna, there ocours in the distel region of the ving-pad of $T_{\text {. }}$ confraterna a white patch corresponding to that found in the cell 155 of the wing of the adult (FIgure 63). 


\section{Plate 25}

view. Figure 62. Mipula fraterna, pupa. (A) doreal vlew, (B) Lateral

Floure 63. Mipula confraterna, wing ped of pupa. 


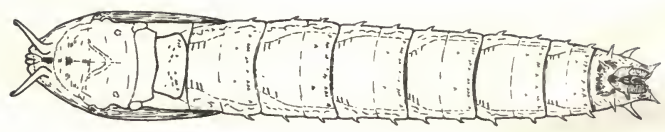

A

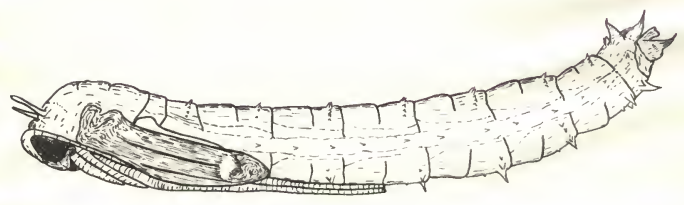

B

62

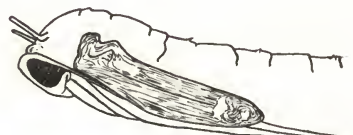

63 
STATUS OF THE FRATERHA COMPIAX IN RETATION TO THE OTHER COMPLEKES OF THE TRTCOLOR GROUP

The analysis of the various characters and structures of the fraterns complex shows rather conclusively the close rolationships of I. fraterns, T. confraterns, and I. strepens. The status of these species in relation to other species has been only brlafly considered in descriptions of the new form and has renatned somewhat obscured by the inablilty to explein certatn characters, 1.e., the wing patterns of the adult forms. Tentative answers to this problem are provided by examinam tion of these species when put Into their varlous compleses and especially by examination of the imature forns. The status of tha freterna complex In relation to the other complexes is described but briefly below. It is based on observations nade of the immatare stages of the tricolor group while stressing the fraterna complex. It is recognised that a much rore complete analyais courd be ande of the tricolor group as a whole, but I Intend only to show what I belleve to be the position of the fraterna ecomplex in relation to the other camplexes.

Immature stages of the tricolor exoup, exclusive of the sayd conplex, vere studied. The position of this camplex has not been detervined because of lack of naterlal. Mlexcander (1920) stated that the eggs of the species within the genus Tipula possessed black chorions. It becene apparent in studyling the varlous complexes that some conplecces hed egge with black chorions or heavily chltintzed chorlons, and others had eggs with pals yellow or 11 ghtly chitinized chorions. Certain correlations of 
the type of chorion could also be made with the larval forms. Those species with the black chorloned eggs developed into larvee which were heavily marised by setae producing dark patterne such as occur on the Larvae of T. caloptera, T. eluta (Nalloch, 1917; Plate XxIx, MIg. 2), and T. furca, and which have, generally, a gray-green coloration. With one exception, eggs with yellow chorions developed into larve uhich w ere characterised by the absence of such maricings and vere generally pale rellow, as in the fraterne and tricolor complexes. The exception was the concava complex, which Alexander (1926) considers as being closely related to T. elute, a nember of the fures complex. This relationship we besed tentatively on afintlerity of the ving patterns. The immature stages of 1 . conceve are peculiar in that the eggs have a yellow chorlon and the larvae are pale yellow, but also possess feeble maridings foming stripes extending from the second or third abdominal segments to the dorso-anterlor vargin of the spiracular disk. This striped pattern is very characteristic of that found in eluta and furca. Thus, coloration of the egge and the body pattern of the larvae five further evidence of a relationship which can be seen in the adult atages, especially in the detalls of the genitalin, as the outer dististyles of species in both the fraterna and tricolor couplexes are atrap-11ke. The genttalsa of I. concava are more Iike those of the furca complex than any other. The probable relationshlp of the fures and caloptere complexes is ahown by the dark chorions of the eggs. The phylogenet1e felationships of the complexes might be as drann in Mgure $64^{\circ}$. 
131.

Plate 26

Figure 64. Dlagram showing relationshlp of fraterne complex. to other couplesses within tricolor group of subgenus Iamatotipula. 


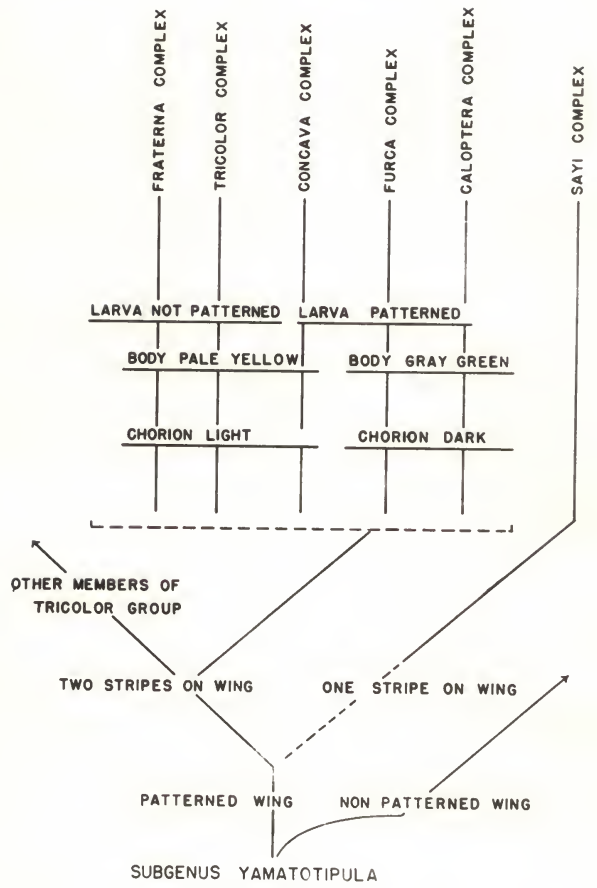

64 


\section{SUMMARY AND CONCLUSIONS}

Within the fantly Tipulsdae there are several groups cornosed of closely related apecies, forming species complexes which are almilar in most deta1 is of morphology, coloration, geographical distribution, and habitats. Within the genus Iipula and the subgenus Ianatotipula, the tricolor group is composed of several of these spectes complexes, one of which is the fraterme complex.

Originally the fraterna complex wes believed to be composed of Pive species: I. Praterns, I. Ploridensis, I. maculipleurs, T. streoens,

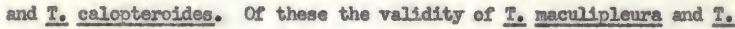
Ploridensis was questioned. Specimens hed also been collected which had a patch of white in the cell $\mathrm{R} 4+5$ of the wings. The status of this form was uncertain but believed to be included within the specles I. Iraterna by previous norkers.

This problen was primarliy concemed with the deterndination of the status of these species, with the exception of I. calopteroldes wich was not consldered for lack of materiel, and the elucidation of their brologtcel relationships.

In order to answer questions as to the validity of the species and the relationship of the fraterna complex to the other species complexses, I traveled extensively collecting edults and irunature stages within the southeastom area. The distribution of all the complexces, and especially that of fraterna, was studied. Sone of the eoologlcal requirenents and 
the Iffe history of I. fraterns and related forms were determined and the reproductive behaviors observed. The morphological and color variar tions were studied, both within a single population for a complete season, and in different populations. The folloring are the conclusions drawn from this atudy.

1. All of the species complexces and all of the species within those complexes are found in the northeastern United States and in southeastern Canada. It is proposed that the complexes and consequently I. fraterns, I. strepens, and I. confreterna had this aree so their conter of dispersal. Avaslable data Indicate that they spresd from this center out to the west and southeast.

2. The distribution of T. Eraterna and To confraterna within the southeast follows closely the margin of the Pledmont from North Carolina to west-central Georgla, then dips southward Into western and north-central Florida. T1pula fraterna exists in nearly all areas from this eastern Iinit to the Mississippi River. It is suspected that edaphic factor along the coastitines and Inland ang not be compatible for the development of the Imonature stages of the two species and may partially explain this distribution. It was shown that $T_{0}$ fraterns and T. confraterns follow the same pattern of distribution.

3. In Michigan, there is only one energence of I. Praterna, during the month of June. This seasonal Iimitation is evldently cherroteristic southward to southern Temessee and northern Alabama. In North and South Carolina the peak energence occurs in June and tapers off toward the and of the surmer. Southward to Morida the emergence is continuous throughout the sumer, but two peaks are observed, one in Mag, the other 
in August. This may not necessarily meen that there are two generetions per year in this region.

4. A study of the ecology of I. fraterna adults and immature stages does not, suggest any correlation with types of vegetation, major or minor. Mosses and Iiverworts with which the inmatures an be associated are thought to be nore indicative of the stability of the strean benks.

5. Physical characteristics of southeastern streams considered neeessary for the presence of I. fraterna are:

(a) scme flow, neither stagnant nor swampy.

(b) a steep benk, not a slowij riaing bank.

(c) a bank in which the so11 18 ccmposed of clav with roots and a certain amount of organic debris in 1t; the lnmature stages were never found in gray- to pepper-colored so1ls nor in banks composed completely of sand.

(d) a bank which is relatively stable.

(e) a streen in which low overhanging vegetation is present for resting areas, to supply protection, and to help maintaln a high huraidty for the adults.

6. The eggs and flrgt instar larvae occupy that area nearest the water surface. It appears that as the larvae increase in sire and age, they migrate upward from the water surface. The pupae are found in the relatively drer areas higher on the bank.

7. Differences between advits of $\mathrm{T}$. fraterna and those of $\mathrm{I}_{\text {. }}$ floridensis were found to be merely variations and not constent, and, for 
that reason, I. Ploridensis is considered to be conspecific with $\mathrm{I}$. Iraterna.

8. The characteristics separating If maculipleurs from I. fraterns were found to be due largely to methods of preservation and care of the gpecinens and of no terconondc significance. Ilpula maculipleurs is therefore considered a gynonym of I. Iraterna.

9. In as moch as the type specimen of I. Iraterma has been lost or destrogred, a neotype has been designated.

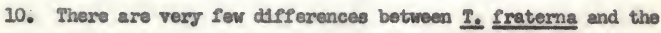
spot-winged form, I. confraterns, in habitat, behavior, morphology, or distribution; but two differences in the morphology are constant: (1) the angle of the tergo-lobe, and (a) the presence of a patch of white in cell Rf of the ving. In addition, the two forms do not mate. Consequently, I consider I. confraterna to be a new species.

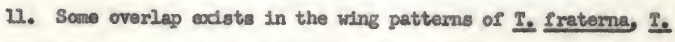
confraterna, and I. Etrepens and may explain why Rogers thought that I. fraterna and I. strepens were intergrading. However, the basic wing patterns remain constant and are correlated with constant differences of the tergo-lobes. All specinens, Including those from the so-called areas of intergradation, were found to lie within the normal range of varlation of the species involved.

12. Based on Evidence from the inmature stages, the fraterns complex is most closely related to the tricolor complex. This conclusion is confirmed by the details of the genstalla of the adult forms. 


\section{ITTERATURR CIIYD}

Alexander, C. P. 1915. New or 11ttle-lonown crane-plies from the United States and Canada: Tipul1dae, Diptera. Part 2. Proc. Phil. Acad. Nat. Se1., 1925: $458-514,87$ PIgs., 6 pls.

- 1920. The crane-Plies of New York. Part II. BloLogy and Phylogeny. Comell Univ. Agr. Ixp. Sta., Memolr 38: 691-1133, pls. XII-XCVII.

- 1926. Undescribed species of crane-211es from the eastem United States and Canads (Dipt.: I1pulidae). Part III. Ent. News, 37(9): $291-297$.

- 1927. Undescribed species of crane-flies fron the eastem United States and Canada (Dipt.: TIpulidae). Part IV. Mant. Nevs, 38(6): 181-184.

- 1935. Hew or 11ttle-known Tipulidae from eastern Asia (Diptera). ax. Philippine Journ. Sel., 57(1): 81-148, 50 flgs., 4 pls.

- 2940. Records and descriptions of North Anerlean crane-flles (Diptera). Part I. Tipuloidea of the Grest Smolg Mountaina National Park, Temessee. Aner. Midland Nat., 2h(3): 602-64h, 48 PIgs.

- 1941. Records and deseriptions of North American crane-Ries (Diptera). Part II. Tipuloidea of mountainous vestern North Carolins. Aner. Mldiand Nat., 26(2): 281-319, 26 Pigs.

- 1942. Fanily Tipulidae. (In The Diptera or true Plies of Connectieut.) Conn. State Ceol. and Nat, Hist. Surv., Bull. 64: 196-509, 11gs. 22-55.

- 1946. Records and descriptions of North American cranewiles (Diptera). V. Tipuloidea of Arisona, New Kexico, and TransPecos Tesas, 1. Amer. Kidland Nat., 35(2): 484-531, 27 P1gs.

- 1951. Notes on the tropical American species of the genus Tipule Innaeus (Mpulidae, Diptera). Part IV. Rev. de IntomoIoglea, 22 (Iasc. $1-3$ ): 265-324.

Anonymous. 1938. Solls of the United States. (In Solls and men, Yearbook of agriculture, 2938.) U. S. Departiment of Agriculture Iearbook. Washington, U. S. Government Printing office, pp. 1019-1161. 
Bader, R. S. 1955. Variability and evolutionary rate in the Oreodonts. Evolution, 9(2): $119-1140$.

Bellany, R. E. 1936. A key for the determination of Florida crane-Plles with records of their geographle and seasonal distribution. Unpublished Master's thesis, Dept. of Blolosy, University of Norids, pp. 1-145, 17 f1ge., 11 pls.

- 2947. The crane-Plies of the Welake area. Unpublished Ph. D. dissertation, Dept. of Blologs, University of Florida, pp. 1-238, 17 IIgs., Il tables.

Berner, L. 1950. The Mayflies of Morida. Univ. of Florida Studies, Bio1. Se1. Ser., IV(4): v11-xd, 1-267, 88 PIgs., 2/4 pls., 29 maps.

Byers, G. W. 1952. The crane- 1 J genus Dollchopeze in North Arearics, Ph.D. dissertation (Publ. No. 3728): University of Michigan. Ann Arbor, Michigan, University Microf1]ns, pp. 1-355, 61 Pigs., I table.

Cook, B. F. 1949. The evolution of the head in the larvae of the Diptera. Microentomolog:, $W_{4}(1): 1-57$, 35 IIgs.

Creaspton, G. C. 1942. The external morphology of Diptere. (in The Diptera of true flles of Connecticut.) Comn. State Geol. and Nat.

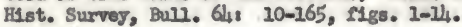

Fernald, M. L. 1952. Gray's manual of botany. New York, American Book Company, pp. v-1xd7, 1-1632, 2806 f1gs.

Foote, B. A. 2956. A preliminary survey of the crane-flles of Delaware County, Ohio (Diptera: Tipuloidea). Ohio Journ. Se1., 56(4): 227-229.

Henmingsen, A. K. 1952. The oviposition of sone crane-rly species (Tipultdae) from different types of locallties. Tidensk. Nedd. dansk Naturh. Foren. Inoh., Ill: 365-430, $6 \mathrm{flgs}$.

Kincer, J. B. 1947. Climate and woather date for the United States (in CIImate and men, Iearbook of agriculture.) U. S. Department of Agriculture Yearbook. Washington, U. S. Covernment Printing office, pp. 700-748.

Loew, H. 1864. Dlptera Americae septemtrionalis indigena. Centurla quints. Berlin. Ent. Zeiticinr., 8: 49-104.

Malloch, J. R. 1917. A preliminary clensiflcation of Diptera exclusive of Pupipara, based on larval and pupal characters, with keys to inagines in certein fandlies. Part I. Bull. III. St. Iab, Nat. Hist., 12(3): 261-409. 
Matsumura, S. 1916. Thousand insects of Jepan. Mdditamente 2. Tokgo, $185-474$.

0ldham, N. N. 1929. On the IInal Larval instax of Tipula paludosa and Tipula laterelia Meig. Proc. Roy. Physlcel Soc., 21: 217-2h1.

Roes, B. E., and G. F. Forris. 1939. The morphology of Tipula rees1 Alexander (Dipters, Tipulidae). Microentomology, 4(6): 143-178, 11gs. $72-91$.

Rogers, J. S. 1930. The armuner crane-51y faune of the Cumberlend Plateku. in Tennesses. Occ. Papers Nus, of 2001. Univ, Mich., 215: 1-50, 5 pls.

- 1933. The ecologicel distribution of the crane-flies of northern Forida. Ecol. Monogr., 3(1): 1-74.

- 1942. The crene-Plies (Mpuldiae) of the George Reserve, Michlgan. Univ, Mich, Mus, Zool. Misc. Publ, No. 53: 1-128, 8 pls.

W1gglesworth, V. B. 2950. The principles of insect physiology, 4th ed. Iondon, Methuen and Co. Ltd., pp. 1-54h, 355 Ilgs. 


\section{BTOGRAPHY}

Claude Dennis thyes was born in Kinnebago, Minnesota, July 10, 1929. He received his prinary and secondary education in the Winnebago public schools and was graduated from Winnebago High School in 1947. He attended Macalester College, St. Paul, Minnesota, Irom 1947 to 1951 , receiving the Bachelor of Arts degree in June, 1951.

He begen hls graduate studies in 1951 at the University of Michigan fron whtch he received the Master of Sclence degree in 1953. His graduate work was cont1nued at the Untversity of Morida Irom 1953 to 1957, durling which time he held succesaively a Research Ass1stantohip and a Teaching Assistantahip.

He is a member of the PhI Signa Society, the Soclety for the Study of Evolution, and the Forida Entomologlcal Soclety. 
This dissertation was prepared under the direction of the chairman of the candidate's supervisory comititee and has been approved by all members of the comaitiee. It was submitted to the Dean of the College of Arts and Selences and to the Graduate Councll and was epproved as partial fulfiliment of the requirements for the degree of Doctor af Philosophy.

August 10, 1957

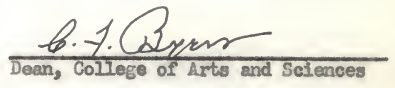

Dean, Graduste School

SUPERVLSORT COMIITRES

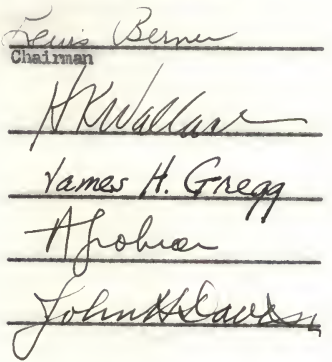

